\title{
Aspects of the Winter Predator-Prey Relationship Between Sauger and Threadfin Shad in Watts Bar Reservoir, Tennessee
}

\author{
M. V. McGee \\ J. S. Griffith \\ R. B. McLean
}

ENVIRONMENTAL SCIENCES DIVISION

Publication No. 1192

Prepared for the U.S. Nuclear Regulatory Commission Office of Nuclear Regulatory Research

Under Interagency Agreement DOE 40-550-75

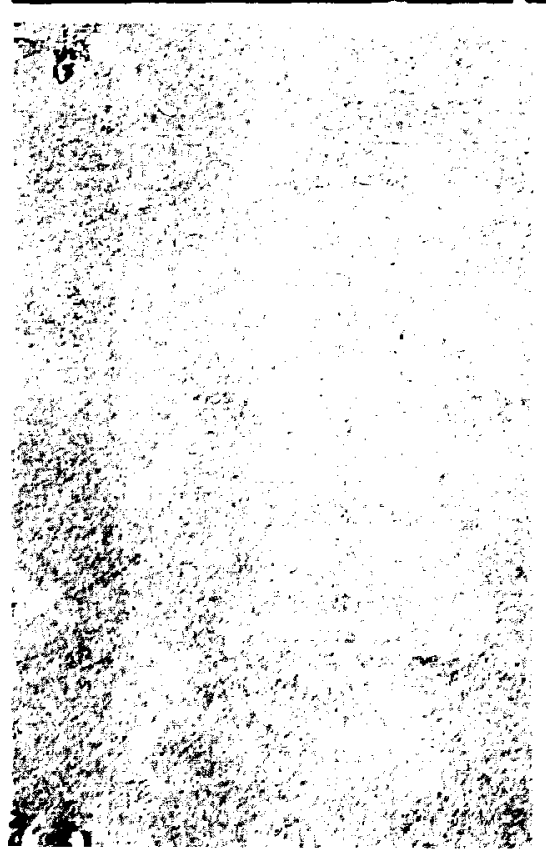


NUREG/CR-0170

ORNL/NUREG/TM-222

Distribution category - RE

Contract No. W-7405-eng-26

ASPECTS OF THE WINTER PREDATOR-PREY RELATIONSHIP BETHEEN SAUGER AND THREADFIN SHAD IN WATTS BAR RESERVOIR, TENNESSEE

M. V. McGee, J. S. Griffith, and R. B. McLean

ENVIRONMENTAL SCIENCES DIVISION

Publication No. 1192

Manuscr ipt Completed - Apri1 1, 1978

Date Published - July 1978

Submitted as a thesis by M. V. McGee to the Graduate Council of the University of Tennessee in partial fulfillment of the requirements for the degree of Master of Science.

Prepared for the

U.S. Nuclear Regulatory Comm ission

Office of Nuclear Regulatory Research

Washington, D. C. 20555

Under Interagency Agreement DOE 40-550-75

NRC FIN No. B0406

Prepared by the OAK RIDGE NATIONAL LABORATORY

Oak Ridge, Tennessee 37830

operated by

UNION CARBIDE CORPORATION

for the

DEPARTMENT OF ENERGY

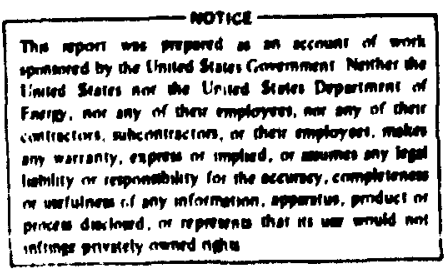




\section{ACKROHLDENENTS}

This research was sponsored in part by the U.S. Muclear Regulatory Comission under Interagency Agreement DOE 40-550-75 and in part by the U. S. Department of Energy under contract W-7405-eng-26 with Union Carbide Corporation.

Special thanks are given to Or. J. L. Wilson, Department of Wildlife and Fisheries, who served as the senior author's graduate comittee chairman and academic advisor. He thank Dr. C. C. Coutant of the Enviromental Sciences Division ORM, Dr. D. L. Bunting, and Dr. D. Etnier of the Department of Zoology, University of Tennessee, who served as additional members of the senior author's graduate committee, for their participation and constructive reviews of the manuscript. He acknowledge the assistance of J. H. Gooch and L. M. Stubbs of the Environmental Sciences Division, ORHL, during the study and Tennessee Valley Authority personnel who participated in sampling and impingement mon itoring. 


\section{ABSTRALT}

McGEE, M. V. 1978. Aspects of the winter predator-prey relationship between saiger and threadf in shad in Watts Bar Reservoir, Tennessee. ORNL/NUREG/TM-222 and NUREG/CR-0170. Oak Ridge National Laboratory, Oak Ridge, Tennessee. $\mathrm{pp} .80$

This study sought to determine the impact of cold-induced mortality and impingement of threadfin shad (Dorsoma petenense) on the fond consumption and prey selection of sauger (Stizostediun canadense), and to estimate the ability of sauger to digest meals consumed at low temperatures in winter. Prey selection by sauger was mon itored from November 1976 through April 1977 in that portion of Watts Bar Reservoir near the Kingston Steam Plant. Stomach contents of 536 sauger collected by gill netting indicated threadfin provided the entire forage base for sauger through January when threadfin rem-ined available and vulnerable due to cold-stress.

Food consumption of sauger was reduced and prey selection shifted to other species arter January due to the combined effects of predation, impingement, and natural mortality of cold-stressed threadfin. Sauger were not directly limited in their food consumption by impingementrelated mortality of threadfin, except perhaps in the vicinity of the intake canal. Impingement of threadfin, monitored concurrently wizh this study, averaged several thousand per day during November and peaked in Decemper at 42,000 in $24 \mathrm{hr}$.

Threadfin shad of a size available to mast sauger were virtually eliminated by February. From February through Apr il some sauger ut il. ized alternate prey species including freshwater drum (Aplodilotus 
grunniens), logperch (Percina caproides), bluegill (Lepomis macrochirus), and mayfly nymphs (Hexagenia sp.), but greater than $75 \%$ of sauger stomachs mere empty. Food consumption of sauger less than $30 \mathrm{~cm}$ was restricted earlier in the year by the lack of threadfin less than approximately $8 \mathrm{~cm}$ in length. Sauger over $42 \mathrm{~cm}$ utilized yearling and oider threadfin (11-15 cm) which remained available longer, probably due to increased cold tolerance. Most sauger retained stores of visceral fat comprising 1 to $9 \%$ body weight during the winter. Fat reserves were greatest in larger, mature sauger.

Laboratory digestion rate studies of sauger indicated digestion of force-fed meals of 4 to $7 \mathrm{~g}$ fathead minnows (Pimephales promelas) could proceed to $90 \%$ completion in $54 \mathrm{hr}$ at $5 \mathrm{C}, 47 \mathrm{hr}$ at $10 \mathrm{C}$, and $25 \mathrm{hr}$ at $15 \mathrm{C}$. Observations on sauger which voluntarily consumed a meal and were later force-fed an equivalent meal indicated digestion was not significantly reduced (T-test $P<0.05$ ), using the force-feeding method. Estimates of digestion rates mere considered accurate enough to est imate the ability of sauger to digest meals consumed in winter in Watts Bar Reservoir.

Conclusions of this study are: (1) that threadfin shad were the most abundant and vulnerable prey species available to and utilized by sauger during the late fall and winter months, while they remained avaflable; (2) extensive mortalities of threadfin due to cold-stress increased sauger predation on four alternate prey species out food consumption was reduced in late winter and spring: (3) sauger continued feeding and digesting meals at temperatures between 5 and $15 \mathrm{C}$ every 1 
to 3 days as estinated by laboratory digestion studies; (4) sauger stored excess energy available from threadfin early in the winter as visce:al fat wich was available later when food consumption was reduced. 
TABLE OF CONTENTS

PAGE

ABSTRACT ......................... v

LIST OF TABLES ..................... . . . . .

LIST OF FIGURES ...................... xi ... . . . .

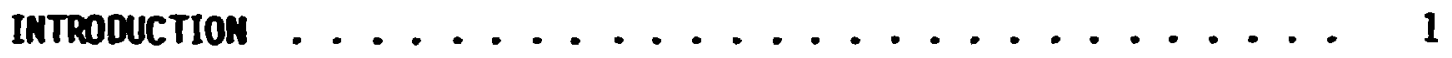

I. RELATED LITERATLRE ................... 3

Sauger. ........................ 3

Vulnerability and Utilization of Threadfin Shad ..... 4

Digestion Rate Studies ............. 5

II. materials aHd Methods ................. 8

Study Area .................. 8

Field C llection of Fish ............ 10

Laboratory Studies of Digestion ............ 11

Compar ison of Force-Fed and Voluntarily Consumed Meals . 15

III. RESULTS: FIELD STUDIES . . . . . . . . . . . . 17

Distribution of Sauger ............... 17

Prey Selection by Sauger ............ 17

Lengths of Sauger and Availability of Threadfin ..... 23

Visceral Fat Content of Sauger ........... 27

Results: Oigestion Rate Studies ............ 27

Effect of Temperature on Digestion ......... 27

Effect of Food Type on Digestion ............ 31

Effect of Force-feeding ............... 31 


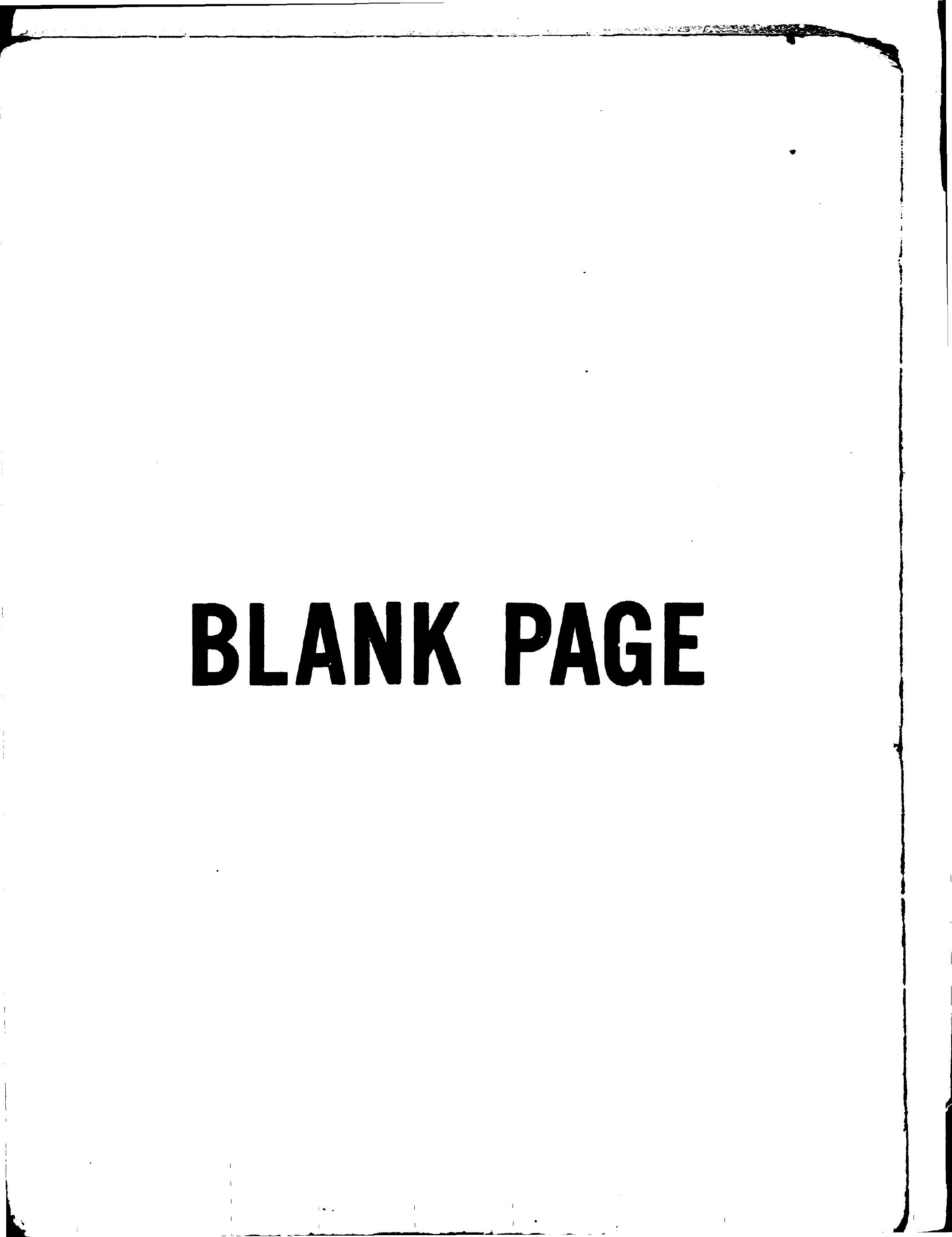




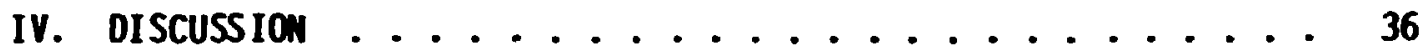

Prey Selection by Sauger as Related to

Impingement and Mortality of Threadfin Shad ........ 36

Application of Digestion Rate Studies.......... 38

Utilization of Food Energy ............. 40

Destabilizing Effects of Cold-Induced Threadfin

Shad Mortality ................. 43

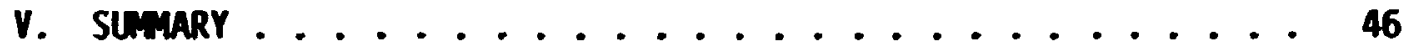

BIBLIOGRAPHY ...................... 48

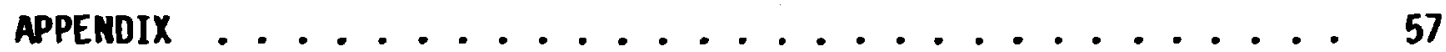




\section{LIST OF TABLES}

\section{TABLE}

1 Rating system used to indicate stage of digestion of food recovered from sauger stomachs captured from Watts Bar Reservoir ................ 12

2 Monthly catches of sauger at each sample site ....... 18

3 Stomach contents of 257 sauger collected in Watts Bar Reservoir, February-April 1977 . . . . . . . . . 21

4 Mear fat content, expressed as $\mathrm{mg}$ fat/g body weight, of 3 size classes of sauger indicating the general relationship between length and visceral fat reserves.... 28

5 Mean percent digestion of force-fed meals of fathead minnows by sauger at 5, 10, and $15 \mathrm{C} \ldots . . . . . .29$

6 Slope coefficients of regression calculated for ind ividual sauger at 5,10 , or $15 \mathrm{C} \ldots . . . . .30$

7 Mean percent digestion by sauger of force-fed meals of threadfin shad at 5 and $10 \mathrm{C} \ldots . . . . . .33$

8 Mean percent differences in digestion of force-fed and voluntarily consumed meals by sauger held at $15 \mathrm{C}$. Sauger consuming similarily sized meals are grouped by meal size expressed as $\mathrm{mg}$ food/g sauger . . . . . . . 35 


\section{LIST OF FIGURES}

FIGLRE

PAGE

1 Location of sampling stations and Kingston Steam

Plant on Watts Bar Reservoir .............. 9

2 Stomach pumping device used to recover partially

digested meals from sauger................ 14

3 Percent occurrence of threadfin shad in sauger

stomachs and percentage of enipty stomachs from

Novenber 1976 through April 1977 ........... 20

4 Average monthly water temperature taken at 3

m for all sample sites............... 22

5 Length-frequency distribution of sauger ......... 24

6 Length distribution of threadf in shad consumed by sauger from November 1976 through February 1977 . . . . 25

7 Percent occurrence by size class of threadfin shad, Dorosoma petenense, in stomachs of three size

classes of sauger, Stizostedion canadense, during

November, 1976 through January, $1977 . \ldots 26$

8 Mean slopes of calculated regression equations

describing the digestion rate for individual sauger

at 5,10 , or $15 \mathrm{C} \ldots . . \ldots 32$

Al Impingement of threadfin shad at the Kingston Steam Plant and water temperature in the intake canal from Novenber

1976 through April 1977 .............. 57

A2 Percent occurrence by size class per unit time of

threadfin shad, Dorosoma petenense, impinged at

Kingston Steam PTant, Watts Bar Reservoir, Tennessee,

November 1976 through Apri1 27, 1977 .......... 58

A3 Comparison of size class distribution of threadfin

shad collected on the intake screens, from sauger

stomachs and in gill nets .............. 59

A4 Comparison of sauger predation on fish species(s) and

impingement. of these species (I), between 2 february

and 26 April 1977 .................... 60 


\section{INTROOUCTION}

Fluctuation in the seasonal abundance and vulnerability of forage species influences fxod consumtion and prey selection of predatory game fish. In most cases naturally evolved constraints on excessive predation and overabundant forage populations maintain predator-prey relationships in a state of dynamic equilibrium. Reservoir impoundnents and stocking of nonnative forage fish in the Tennessee Valley have resulted in establishment of new predator-prey interactions occurring between previously allopatric species. These relationships may be less stable than those occurring naturally and exhibit unique characteristics, as determined by the ecological responses of the affected populations.

Interest in quantifying the dynamics of a predator-prey relationship existing under these conditions led to this study of sauger (St'zostedion canadense) and threadfin shad (Dorsoma petenense) during the winter months in Watts Bar Reservoir, Tennessee. This relationship is unique in that the relatively cold-tolerant sauger is feeding in fall and winter primarily on threadfin shad, a cold-sensitive, nonnative prey species.

This study was conducted as a subproject of a larger investigation by a team of researchers into the physical and biological causes and effects of threadfin shad impingement at the Tennessee Valley Authority Kingston Steam Plant. The research was funded by the Environmental Sciences Division of the Oak Ridge National Laboratory under contract with the Nuclear Regulatory Commission and the Department of Energy. The key objectives of the subproject were to (a) define the importance 
of cold-stressed threadfin shad in the diet of sauger, and (b) determine the extent to wich power $p l$ ant operation may affect this utilization. The specific objectives mere (a) to determine the effects of coldinduced vulnerability, impingement, and mortality of threadfin shad on the food consumption and prey selection of sauger; and (b) to estimate how rapidly sauger can digest meals consumed at low temperatures. Because of the extensive nature of the threadf in shad impingement study much of the data kere collected as a team effort. For this reason some figures, cited support observations, and results of the subproject are included in an appendix. This information represents results obtained from data from other subprojerts within the scope of the larger project, and analyzed by the author and $h$ is research advisors. 
CHAPTER I

\section{RELATED LI TERATURE}

\section{Sauger}

The sauger [Stizostedion canadense canadense (Smith)] is a cool-water fish species which exists in Tennessee near the southeastern margin of its range. Sauger are members of the tribe Luciopercini, subfamily Luciopercinae, family Percidae, and are most closely related to the walleye (Stizostedion vitreum vitreum). Important ecological differences between the species are the smaller adult size of the sauger, its closer association with the bottom, and a preference for more turbid, flowing water (Nelson and Halburg 1977, Ali et al. 1977, Swenson 1977).

Sauger are a successful species in many Tennessee reservoirs. The growth rate of Tennessee sauger is the most rapid reported for the species during the first two years of life (Stroud 1949, Hass ler 1953). This is attributed to the relatively long growing season and abunoint food supply available in Tennessee waters. Sauger in Lewis and Clark Lake, South Dakota, attained a slightly greater length after three years of life (Nelson 1969), but elsewhere in northern waters, sauger grew at a slower rate and survived to a greater age (Carufel 1963, Carlander 1950, Hart 1928, Priegel 1969, Carter 1968).

Sauger become picivorous at an early age. Priegel (1969) found sauger as small as $50 \mathrm{~mm}$ consumed the fry of trout perch (Percops is omiscomaycus), white bass (Morone crysops), and freshwater drum 
(Aplodinotus grunniens). As adults, sauger feed to a large extent on the most abundant forage species available to them. In northern waters these are usually trout perch, yellow perch (Perca flavescens), and emerald shiners (Notropis atherinoides) (Swenson and Smith 1976, Priegel 1963). In Tennessee, young-of-the-year shad (Dorsoma spp.) provide the bulk of the for age requirements for sauger espacially in winter (Dendy 1946a, Hassler 1953, Dryer and Benson 1957).

Vulnerability and Utilization of Threadf in Shad

The importance of young clupeids, especially the threadfin shad (Dorsoma petenense), and gizzard shad (‥ cepedianum), in providing forage for game fish is well known (Dendy 1946a, Lew is et al. 1974, Range 1973, Aggus 1973, Pasch 1974, Scott 1976). Threadf in shad are native to the area of the Gulf Coast drainage, but have been widely introduced as a forage species because of the ir small size and vulnerability to predators (Minckly and Krumholtz 1960, Ihrie 1970). The vulnerability of threadfin shad to predation is increased by coldinduced behavior changes which are man ifest at water temperatures below approximately $10 \mathrm{C}$ (Griffith 1978). These changes result in decreased swiming and schooling abilities and may advance to a state of unresponsive torpor at temperatures below $7 \mathrm{C}$.

For similar reasons low temperatures also increase susceptibility of the threadfin to impingement on intake screens in lakes supplying cooling water to electrical generating facilities (Griffith and Tomljanovich 1976). Threadfin shad constitute $90 \%$ of all fish impinged at 32 power plants in 16 southeastern states (Loar et al., in press). 
During winters of rapid temperature drop or sustained la temperatures, natural mass mortalities of threadfin may result (Huhbs 1951, Parsons and Kimsey 19ist, Hassler 1953, Dryer and Benson 1957).

\section{Digestion Rate Studies}

To estimate the ability of sauger to utilize threadfin shad during the late fall and winter when water temperatures are low, the effect of temperature on the digestion and consumption rates of fishes must be considered. Comprehensive reviews of the historical development, methods, and applications of digestion rate studies have been provided by Windell $(1966,1968)$. The effects of different food items, mixed meals, meal size, starvation, and fat on digestion rates are also considered. Palohimo and Dickie (1966) summarized exper imental data on the effect of temperature on the relationship between metabolism and body wight of $f$ ish and concluded there was an increased rate of metabolism with increasing temperature. Seaburg and Moyle (1964) est imated food consumption and digestion rates of several species of fish during the sumer months. Digestion rates of centrarc':d panfishes were faster than the larger game fish. Markus (1933) investigated the effects of temperature on food consumption of the largemouth bass (Micropterus salmoides). Metabolism was very $10 w$ at $4 \mathrm{C}$ and increased rapidly up to $22 \mathrm{C}$, after wich the rate of increase was diminished. The magnitive of change in gastric evacuation of rainbow trout (Salmo gairdnari) was greater at low temperatures of 0 to $5 \mathrm{C}$ than higher temperatures of 15 to $20 \mathrm{C}$ (Windell et al., 1976). A depressed rate of digestion and reduced conversion efficiency at low temperatures was noted for sockeye 
salmon (Oncorhynchus nerka) (Brett and Higgs 1976). Digestion rate, however, showed a compensatory in:rease of $33 \%$ over that predicted by the calculated regression line at $3 \mathrm{C}$. The authors concluded that digestion may be the chief limiting factor to food consumption and growth at low temperatures. A study of winter food habits of six species of fish revealed some feeding by individuals of all species and that food specializations were reduced (Keast 19ö8).

Information from the literature reviewed indicates that Stizostedion Spp. will continue to feed and digest meals at low temperatures, although at a reduced rate. Molnar et al. (1966) developed a method of $X$-ray analys is to measure the gastric digestion of pike-perch (Stizostedion lucioperca). Results indicated emptying of the stomach was 8 to 9 times slower at $5 \mathrm{C}$ than at $25 \mathrm{C}$. The author concluded that food consumption would be reduced and abundant food supplies in winter would be largely unexploited. In another study pikeperch required from 4 to 9 days to digest a meal when water temperatures ranged between 0.1 and $8 \mathrm{C}$. Active feeding and intensive digestion boyan at 3 to $10 \mathrm{C}$ (Popova and Sytina 1977). Galligan (1960) examined the stomach contents of walleye collected by icefishing and concluded that the absence of food might simply be a matter of availability of the prey species at the time. In Tennessee, walleye and sauger were well filled with shad during the winter months and had an abundance of visceral fat iDendy 1946, Stroud 1949, Hassler 1953, Oryer and Benson 1957, Scott 1976). Growth in length of walleye and sauger does not occur during the winter months at temperatures below approximately 12 C (Hassler 1953, Kelso 1972;, and excess energy appears to be stored in tissues or as 
visceral $\mathrm{fat}$. Kelso (1973) suggest that energy stored as fat may make a significant contribution to the energy budget of walleye. Fat reserves of sauger may also be utilized as an energy source when food consumption is reduced.

Predation by sauger on threadfin shad during the late fall and winter months is expected to be facilitated by the cold-induced behavior changes affecting the shad. However, natural mortalities and higher rates of impingement resulting from cold stress of threadfin may decrease forage available to sauger. Reduction in growth rates and fecundity of Stizostedion Spp. has been attributed's a limited food supply resuliing from poor reproduction of prey species or extensive winter kill of these forage fish (Forney 1965, Eschemeyer and Smith 1943, Nelson 1969). 
CHAP IER II

\section{MATERIALS AMO METHOOS}

\section{Study Area}

Hatts Bar Reservoir is a 13,300-ha impoundment wich was created in 1942 by the completion of Hatts Bar Dam at Tennessee River Mile 529.9. The lock and dan are situated approximately $80 \mathrm{~km}$ southwest of Knoxville, Tennessee. The reservoir has three main tributaries, the Little Tennessee River, the Clinch River, and the Emory River. The upper portion of the reservoir is characterized by the riverine reaches of the Emory, Clinch, and upper Tennessee tributaries (Fig. 1). Watts Bar extends up the Little Tennessee River for $1.6 \mathrm{~km}$, up the Emory for $19 \mathrm{~km}$, and up the Clinch for $37 \mathrm{~km}$ to the tailwaters of Melton Hill keservoir.

The Tennessee Valley Authority's Kingston Steam Plant is located on Watts Bar Reservoir at Clinch River Mile 2.7. The plart has a generating capacity of $1700 \mathrm{mw}$ and withdraws a total of $65.4 \mathrm{~m}^{3} / \mathrm{sec}$ of cooling water from the intake canal (site 3, Fig. 1). In winter, cooling water may be orawn from either clinch or Emory sources, depending on reservoir level and temperature and flow or each source. Temperature in the discharge canal (site 6, Fig. 1) is elevated $7.8 \mathrm{C}$ above ambient at maximum power generation.

Watts Bar is a mesotrophic system, and supports a number of native and introduced fish species of sport, commercial, and ecological importance. Cove rotenone surveys by TVA biologists during the period 19491973 identified a total of 11 families and 50 species inhabiting 


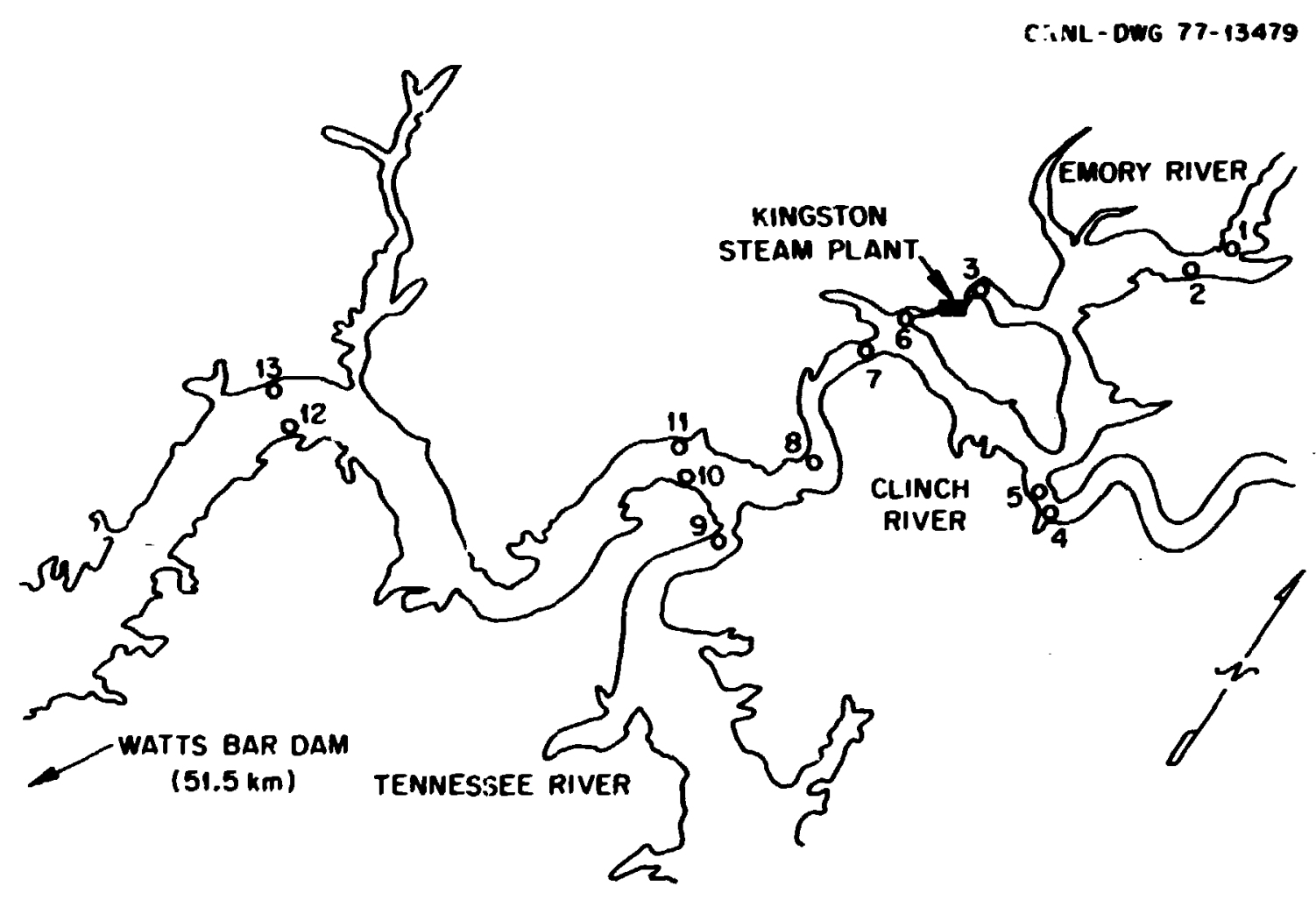

Figure 1. Location of sampling stations and Kingston Steam Plant on Watts Bar Reservoir. 
the lake (TVA unpublished manuscript 1974). Sauger are the daminant coolwater species and walleye are caught only occasionally in Matts Bar.

\section{Field Collection of Fish}

Saipling was conducted from November 1976 through April 1977 as part of the tean research into the ecological significance of threadfin shad impingenent. Thirteen netting sites were selected in upper Watts Bar Reservoir (Fig. 1) within nine river miles $(14.5 \mathrm{~km})$ of the stean plant and included its intake and discharge canals. Data for the project was collected in three basic ways, impingenent monitoring, gill netting, and seining or electrofishing for threadfin shad. 6ill nets were of primary importance for collection of sauger for stomach content analysis. Sauger and other fish species were caught in bottom set gill nets of graduated bar mesh (13 to $51 \mathrm{~mm}$ in 13-m increments). Nets were set for $24 \mathrm{hr}$ each week at stations 1 to 6 and for $24 \mathrm{hr}$ bi-weekly at stations 7 to 13. Temperature profiles and Secchi disc readings were taken at the time of each set. Fish mere prucessed (or frozen for later examination) within $3 \mathrm{hr}$ after nets were pulled.

Total length in centimeters and weight in grams of all sauger were recorded and sex of mature individuals was determined. Immature sauger were not sexed. Scale samples of sauger were collected from the left side just below the lateral line at the posterior extension of the pectoral fin. Stomach contents were enumerated and identified to the lowest possible taxa. Percent digestion of stomach contents was est imated using a rating system developed from comparison with partially digested meals of a known size recovered from sauger held in the laboratory 
(Table 1). Care was taken to identify sauger which had regurgitated stomach contents, evidenced by distended but empty stomachs and of ten accompanied by the presence of egested material in the fish's throat and nouth.

\section{Laboratory Studies of Digestion}

Digestion studies were conducted from January through August 1977 in 770-liter circular fiberglass tanks with a continuous fla of temperature-controlled well water. Temperatures were held at 5, 10, or $15 \mathrm{C}( \pm 1.0 \mathrm{C})$. A photocell regulated laboratory lighting to simulate ambient day lengths. Tanks containing sauger were covered with two layers of heavy canvas wich reduced light intensities to 1 foot candle at the surface, as measured by a photometer. Reduction of ambient light levels was necessary because sauger are adapted to a low-light environment and seldom experience high subsurface illumination (Ali et a). 1977).

Sauger used in experiments mere collected from Watts Bar Reservoir and ranged in size from $33.2 \mathrm{~cm}(277 \mathrm{~g})$ to $47.4 \mathrm{~cm}(1150 \mathrm{~g})$. Sauger were grouped into size classes, and individuals from each size class were randomly assigned to each tank. This resulted in approximately equal size distribution and total weight of fish in each experimental group. Densities never exceeded eight sauger per tank.

During an acclimation period of two weeks, sauger were given prophylatic treatments of $1 \mathrm{ppm}$ malachite green dissolved in the tank water to minimize the risk of bacterial and fungal infections resulting from the stress of capture and handling. Attempts were made to induce 
TABLE 1

Rating system used to indicate stage of digestion of food recovered from sauger stomachs captured from hatts Bar Reservoir. Percent digestion was estimated by comparison with partially digested meals of a known size recovered from sauger held in the laboratory.

\begin{tabular}{cl}
\hline Condition & \multicolumn{1}{c}{ Description } \\
\hline$A_{1}$ & $\begin{array}{l}\text { Prey was nearly intact, identified to species, total length } \\
\text { and weight was recorded. Digestion 0-20\%. }\end{array}$ \\
$A_{2}$ & $\begin{array}{l}\text { Prey partly digested, identified to species if poss ible, } \\
\text { length and weight recorded. Digestion 20-40\%. }\end{array}$ \\
$B_{1}$ & $\begin{array}{l}\text { Prey digested but still fairly intact, length estimated and } \\
\text { weight recorded. Digestion } 40-60 \% .\end{array}$ \\
$B_{2}$ & $\begin{array}{l}\text { Prey well digested but still identified by anatomical } \\
\text { features as gizzards or otoliths. Length estimated and } \\
\text { weight recorded. Digestion } 60-30 \% .\end{array}$ \\
$C_{1}$ & $\begin{array}{l}\text { Identifiable fish remains. Identified by anatomical features } \\
\text { if possible. Digestion } 80-95 \% .\end{array}$ \\
$C_{2}$ & Digested material. Identified if possible. Digestion $95+\xi$. \\
Rg & Stomach empty. \\
& Stomach contents regurgitated.
\end{tabular}


voluntary feeding in all experimental groups. When these attempts failed, a force-feeding method was adopted.

Force-feeding of experimintal meals. A method of force-feeding was necessary because sauger held at 5 and $10 \mathrm{C}$ in the laboratory would not voluntar ily consune minncus introduced on a restricted feeding schedule. Prior to handling, saugser were anesthesized with is 222 until quiescent. Exper imental meals, approximating 1 to 26 boiy weight of sauger, consisted of 4 to $7 \mathrm{~g}$ of 1.5 to $2.0 \mathrm{~g}$ fathead mimows (Pimsiphales promelas:, or 4 to $7 \mathrm{~g}$ of threadfin shad. Meal sizes were expressed as milligranis of food per gran of sauger. Force-feeding was accomplished by placing the food items in the saugers mouth and gently pushing then headfirst into the esophageal opening with a blunt-ended glass probe. Once introduced, food was readily swallowed and regurgitation of meals was not a problem.

When an experiment was begun all sauger were fed an initial meal of 4 to $7 \mathrm{~g}$. This preliminary meal was necessary to supply energy requirements of sauger as well as stimulate enzyme production, ensuring more normal digestion. After allowing for complete digestion of the first meal, sauger were held $24 \mathrm{hr}$ without food before being fed the exper $\mathrm{i}$ mental meal. Digestion was allowed to proceed for $6,12,18,24,48$, or $72 \mathrm{hr}$, depending on exper imental conditions. Digestion time for all sauger during any one experiment was held constant.

food remains were recovered by pumping stomachs of anesthesized fish using the device illustrated in Fig. 2. The method was adapted from that described by Swenson and Smith (1973). Use of blunt-ended glass tubing of 12, 14, 16, or 18-im diameter prevented damage to throat 
OPAL-DUS 78-2703

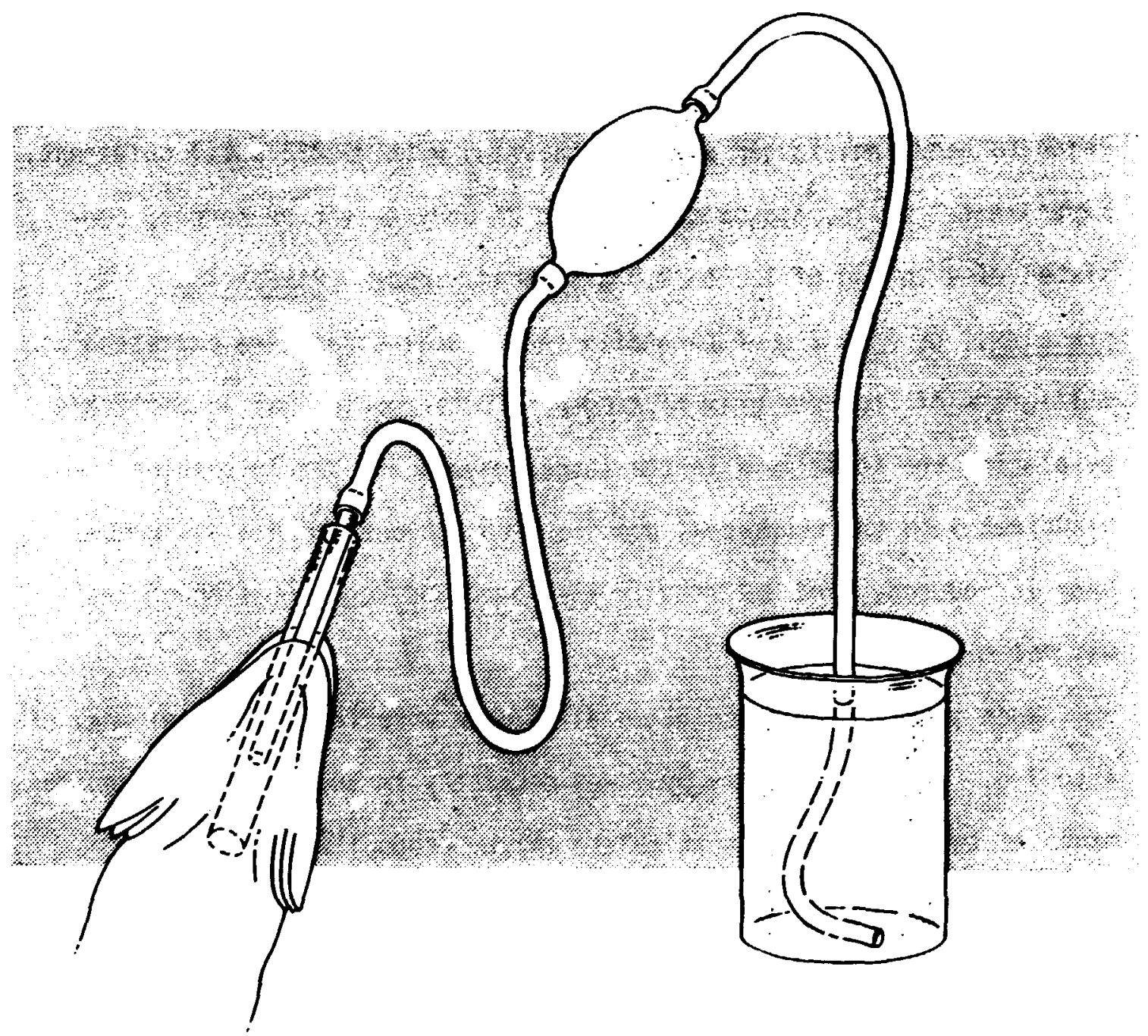

Figure 2. Stomach pumping device used to recover partially digested meals from sauger. Inflowing water backflushed food material into the larger diameter glass tubing. 
and stomach linings and allowed visual determination of when stomach pumping was complete. Food recovered from stomachs was blotted dry and weighed to the nearest $0.1 \mathrm{~g}$. Weights of digested meals were compared to original weights and digestion was expressed as the percent reduction which occurred in the tine allowed.

Statistical methods. Regression equations describing the percent digestion which occurred during the time interval allowed were computed for individual sauger held at 5, 10, or $15 \mathrm{C}$ using the method of least squares regression with replicated data (Sokal and Rohlf 1969). In most cases two digestion experiments at each time interval were conducted for each fish. All regressions were calculated as passing through the or $i-$ $g$ in under the assumption that percent digestion was zero at time zero. Slope coefficients of the regressions for individual sauger at each temperature were combined and the mean slope determined. These slopes provided est imates of the time required by sauger to digest force-fed meals at 5,10 , and $15 \mathrm{C}$. These estimates were used to predict the ability of sauger in Watts Bar Reservoir to digest meals consumed at low temperatures in winter.

Comparison of Force-fed and Voluntarily Consumed Meals

In these experiments the effect of force-feeding on digestion was determined. Twenty-two sauger, ranging in size from 25.1 to $40.2 \mathrm{~cm}$ were placed in a covered 1500-liter circular tank with continuous flow of temperature-controlled well water held at $15 \mathrm{C} \pm 1.0 \mathrm{C}$.

These fish were conditioned to accept meals of $1.5 \mathrm{~g}$ minnows $( \pm 0.1 \mathrm{~g})$ within a one-half-hour perlod by shortening the time food was 
made available. At the start of an experiment sauger were fed for two days on this restricted schedule. The fish were then denied food for 24 hr prior to introducing approximately 50 1.5-g (1X total sauger weight) minnows for one-half hour. Digestion of voluntarily consumed minnows was allowed to proceed for $8 \mathrm{hr}$, after which time the remaining food was recovered by pumping stomachs, and fercent digestion and meal size were determined. Sauger were returned to the tank and fed normally for four days before completing the experiment.

During the second phase of the experiment sauger were fed two days on the restricted schedule and then denied food for $24 \mathrm{hr}$. At this $t$ ime, those sauger which had voluntarily consumed a meal were force-fed an equivalent meal of $1.5-\mathrm{g}$ minnows, with all other exper imentai conditions held constant. Percent digestion of force-fed and voluntarily consumed meals was determined for each individual and the difference between the two feeding methods calculated by subtraction. Data from sauger consuming similarly sized meals, expressed as $\mathrm{mg}$ food/g body weight, were combined and mean differences in digestion of force-fed and voluntary consumed meals calculated for each group. These differences were tested using a T-test to determine if the mean at each meal size differed significant ly from zero. 
CHAP TER III

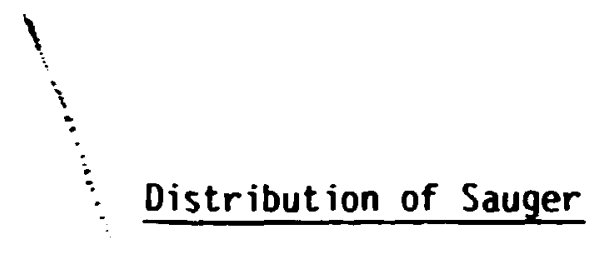

Monthly catches of sauger varied between sample sites (Table 2) and were irfluenced by net size and sampling frequency but indicated areas of sauger concentrations. Sites 4 and 5 on the $C l i n c h$ river and site 8 at Kingston Park produced the greatest numbers of sauger durirg the study. Sauger were abundant in the intake canal (site 3) duri:ig November and December and again in March. Sauger did not concentrate in the discharge canal of the steam plant during the winter months.

\section{Prey Selection by Sauger}

Stomach contents of 536 sauger were examined. Seven percent of these fish were judged to have regurgitated stomach contents with no apparent correlation with collection date or location. Such stomachs were not inciuded in the prey selection analysis. Food consunied by sauger was usually recognizable even in advanced states of digestion because of distinct morphological and anatomical characters such as body shape, spiny rays, otoliths, and gizzards.

Examination of sauger stomachs revealed that food consumption and prey selection differed substantially during two distinct time periods (November to January and February to Apri1). These periods corresponded with changes in threadfin shad abundance as effected by predation, coldinduced impingement, and mass mortality. 
TABLE 2

Monthly catches of sauger at each sample site. Catches were influenced by net size and sampling frequency but indicate areas of sauger concentration and patterns of movement.

\begin{tabular}{|c|c|c|c|c|c|c|c|}
\hline \multirow[b]{2}{*}{ Sample Site } & \multicolumn{7}{|c|}{ Sauger Catch by Month } \\
\hline & Nov & Dec & Jan & Feb & Mar & Apr & Total \\
\hline Emory $(1+2)$ & 3 & 1 & 0 & 0 & 9 & 1 & 14 \\
\hline Intake (3) & 16 & 22 & 0 & 1 & 13 & 2 & 53 \\
\hline Clinch $(4+5)$ & 4 & 32 & 21 & 20 & 77 & 1 & 155 \\
\hline Discharge (6) & 6 & 0 & 0 & 0 & 4 & 0 & 10 \\
\hline $1-40(7)$ & 2 & 26 & 1 & 3 & 10 & 0 & 42 \\
\hline Kingston Park (8) & 10 & 88 & 6 & 32 & 17 & 6 & 159 \\
\hline 58 Bridge (9) & 19 & 4 & 3 & 5 & 2 & 0 & 33 \\
\hline Forks Left $(10)$ & 2 & 3 & 1 & 2 & 12 & 3 & 23 \\
\hline Forks Right (11) & 1 & 6 & 0 & 6 & 1 & 0 & 14 \\
\hline $\mathrm{Rm} .562$ Left (12) & 7 & 8 & 0 & 1 & 7 & 0 & 23 \\
\hline Rm. 562 Right (13) & 6 & 6 & 0 & 1 & 2 & 2 & 17 \\
\hline TOTAL & 76 & 196 & 32 & 71 & 154 & 15 & 543 \\
\hline
\end{tabular}


From November through January, threadfin shad occurred as the only positively identified prey species in the 243 sauger stomachs examined (Fig. 3). Fifty-two percent of sauger that preyed on threadfin contained more than one in the stomach, with a maximum of seven. Sauger that consumed multiple threadfin usually contained two or three. Such prey were usually in different states of digestion, but in some cases up to five were judged to be taken at the same feeding. Unidentified remains occurred in $10 \%$ of the stomachs and $17 \%$ of the stomachs were empty during this period.

Throughout February the occurrence of threadfin shad in sauger stomachs progressively decreased. The frequency of empty stomachs and utilization of alternate prey showed a concomitant increase (Table 3 ). During February, freshwater drum accounted for $44 \%$ of identified prey and threadfin shad for the remaining 56\%. Two-thirds of the 67 stomachs checked were empty.

By March, threadfin shad were not found in any sanger stomachs. Freshwater drum, logperch (Percina caprodes), bluegills (Leponis macrochirus), and mayfly nymphs (Hexagenia sp.) comprised the total of identifiable prey utilized in March and April. Combinations of more than one species of prey in a single stomach were never observed. During these two months, $82 \%$ of the 168 sauger stomachs examined were empty.

Variations in mean monthly water temperatures existed among sample sites (Fig. 4) and affected the rates at which sauger could digest meals. Temperatures below $5 \mathrm{C}$ occurred at all sites except thermally affected areas (sites $6,7,8$ ) during January. By late February mean 


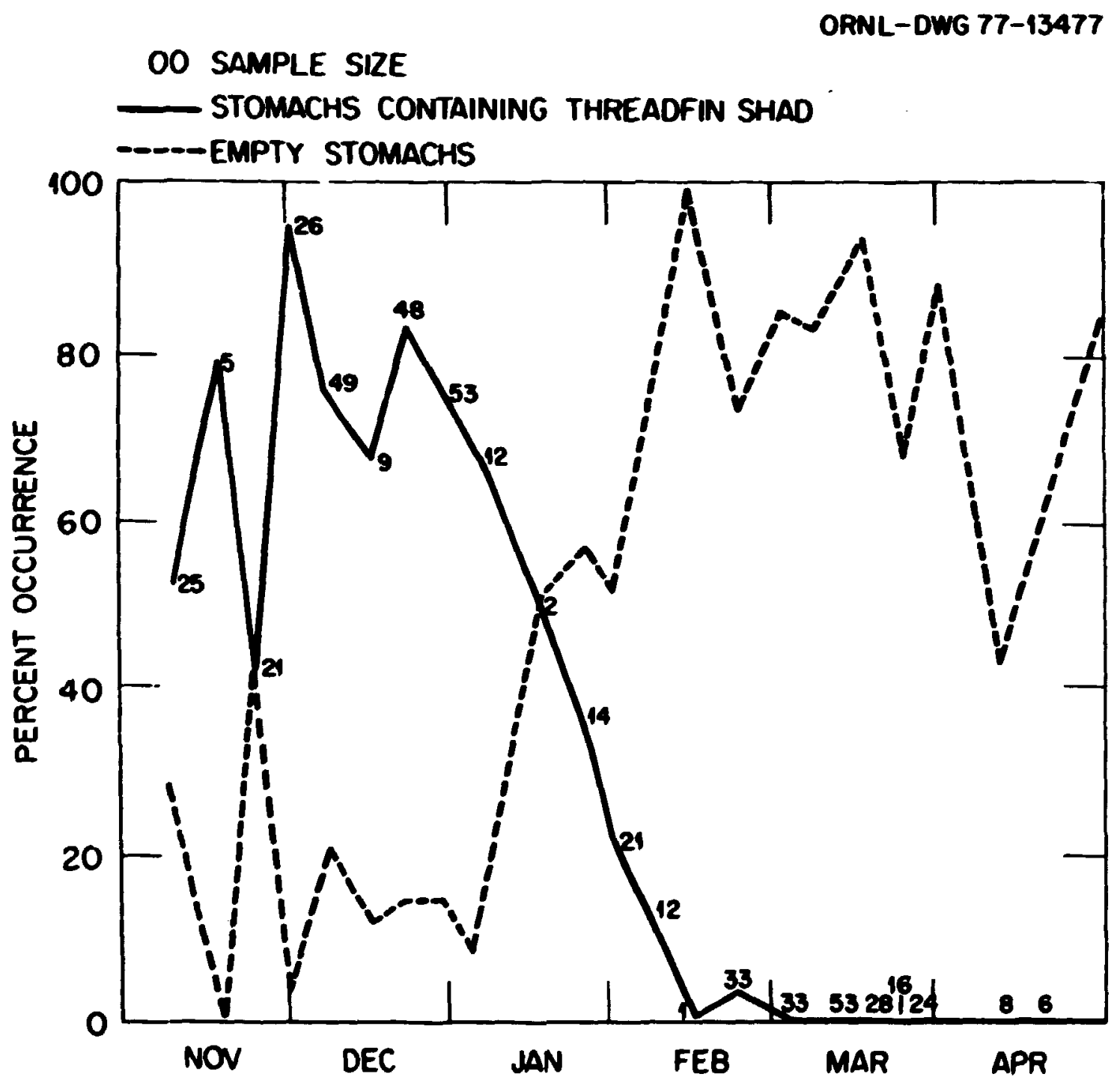

Figure 3. Percent occurrence of threadfin shad in sauger stomachs and percentage of empty stor:-hs from Novenber 1976 through April 1977. Numbers represent sample size during each week. 
TABLE 3

Stomach contents of 257 saiger collected in Watts Bar Reservoir, February - April 1977.

Data from all sites combined.

\begin{tabular}{|c|c|c|c|c|c|c|c|c|}
\hline \multirow{2}{*}{$\begin{array}{l}\text { Collection } \\
\text { Date }\end{array}$} & \multirow{2}{*}{$\begin{array}{l}\text { Numher of } \\
\text { Sinder }\end{array}$} & \multicolumn{7}{|c|}{ Number of Stonachs Containing } \\
\hline & & Threadf in & Drum & Logperch & Bluegtil & Mayflies & Unidentified & Empty \\
\hline Feb. $\begin{array}{r}2 \\
9 \\
16 \\
23\end{array}$ & $\begin{array}{r}21 \\
12 \\
1 \\
33\end{array}$ & $\begin{array}{l}7 \\
2 \\
1\end{array}$ & 2 & & & & $\begin{array}{l}1 \\
1 \\
3\end{array}$ & $\begin{array}{r}11 \\
9 \\
1 \\
24\end{array}$ \\
\hline $\begin{array}{r}2 \\
9 \\
17 \\
24 \\
30\end{array}$ & $\begin{array}{l}33 \\
53 \\
28 \\
16 \\
24\end{array}$ & & $\begin{array}{l}2 \\
2 \\
1\end{array}$ & $\begin{array}{l}1 \\
1 \\
1\end{array}$ & $\begin{array}{l}1 \\
1 \\
1\end{array}$ & 1 & $\begin{array}{l}2 \\
4 \\
1 \\
3 \\
2\end{array}$ & $\begin{array}{l}28 \\
44 \\
26 \\
11 \\
21\end{array}$ \\
\hline $\begin{array}{rr} & 6 p r . \quad \\
13 \\
26\end{array}$ & $\begin{array}{l}0 \\
8 \\
6\end{array}$ & & 1 & 1 & 2 & 1 & 1 & 3 \\
\hline
\end{tabular}




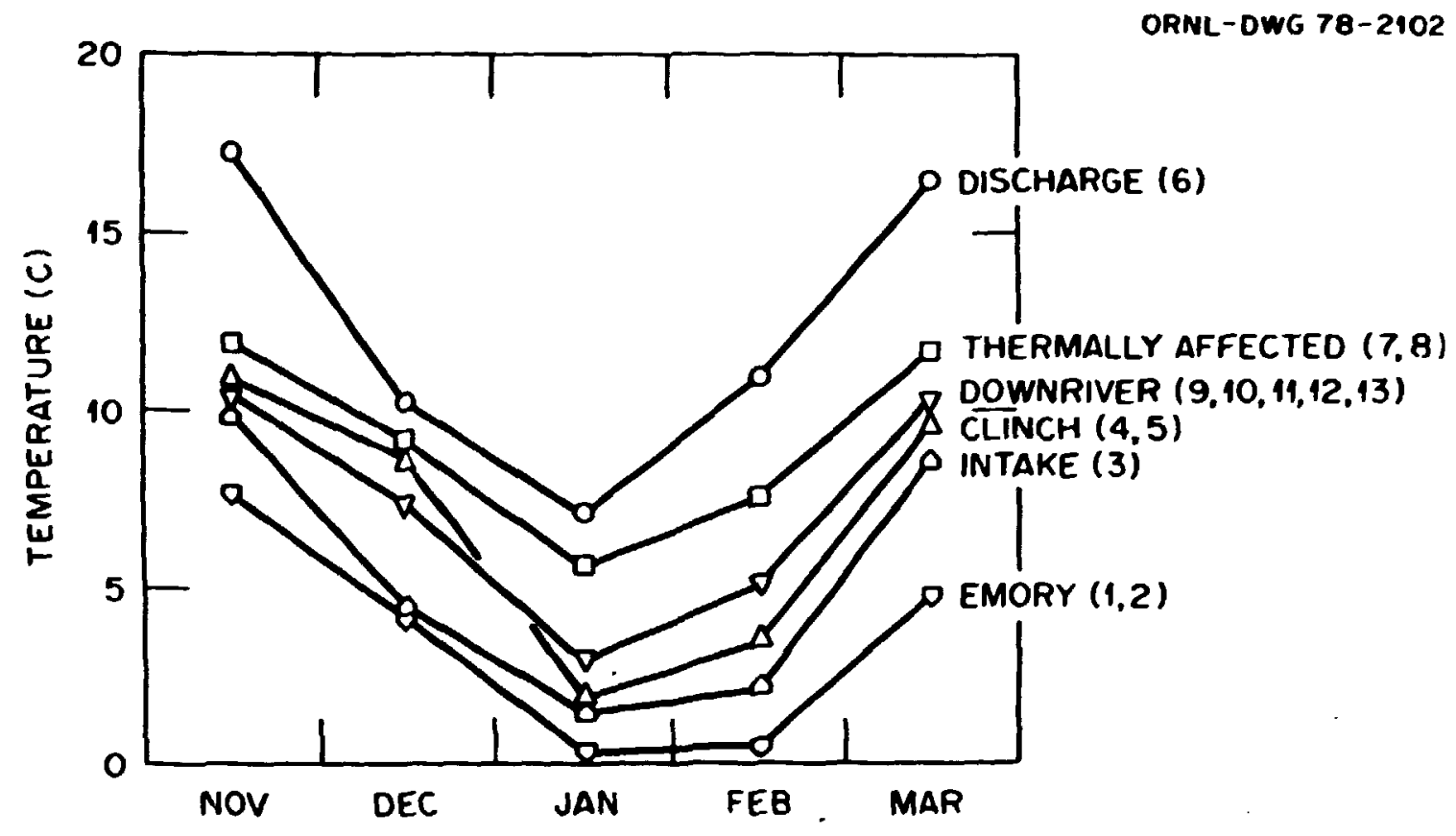

Figure 4. Average monthly water temperature taken at 3 meters for all sample sites. Thermally similar sites are combined. 
water temperatures had $r$ isen above $5 \mathrm{C}$ at all stations except in the intake canal and the Emory river (sites 1, 2, 3). In March, temperatures warmed to levels to around $10 \mathrm{C}$, comparable to those of late November, but food consumption remained low.

Lengths of Sauger and Availability of Threadf in

A length-frequency distribution of sauger indicates size differences existed between mature male, female, and immature sauger (Fig. 5). These size differences due to sex and age affected the availability and utilization of threadfin and determined the size range of threadfin which could be consuned by sauger (Fig. 6).

The majority of threadf in consumed by sauger were young-of-the-year 8-10 $\mathrm{cm}$ in length. Scale reading of threadfin shad in January by Dr. J. S. Griffith determined the break in size between young-of-the-year and.older threadfin was approximately $11 \mathrm{~cm}$. Sauger over $42 \mathrm{~cm}$ also utilized yearling and oldsr threadfin up to $15 \mathrm{~cm}$ in length. Lengths of threadfin recovered from stomachs ind icate that larger threadfin remained alive and available to these sauger at least through January (Fig. 7).

Mature female sauger were the most abundant in those size classes of sauger which could utilize threadfin greater than $11 \mathrm{~cm}$ in length (Fig. 5). This resulted in a wider size range of food available to these females and increased food availability throughout the winter. Sauger under $30 \mathrm{~cm}$ in length consumed very few threadfin in winter, probably because of the unavaflabflity of shad less than $10 \mathrm{~cm}$. Maximum lengths of threadfin consumed by sauger ranged from 29 to $35 \%$ of body 


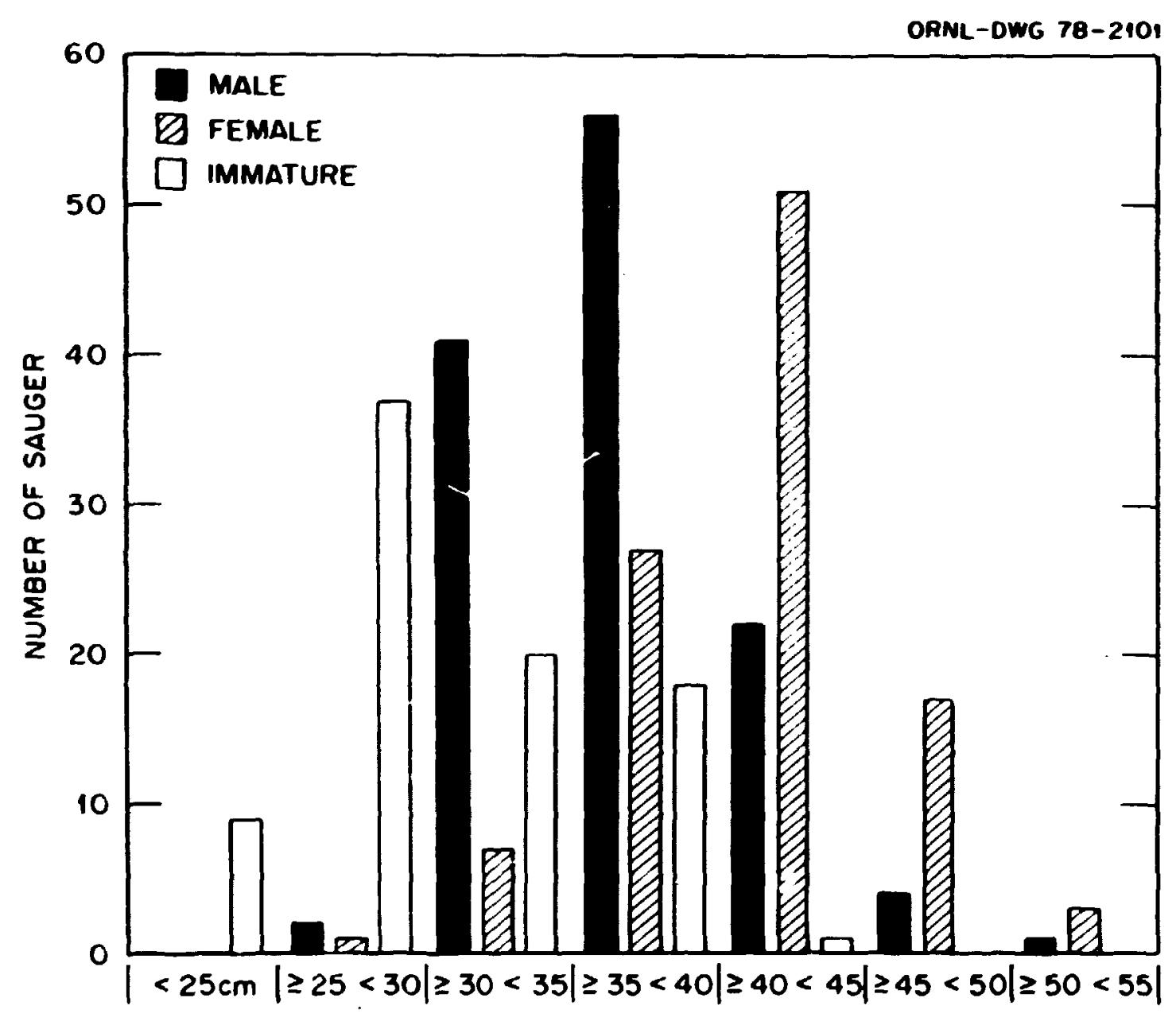

Figure 5. Length-frequency distrioution of sauger. Sauger are grouped as mature male, mature female, or inmature $s$ auger. 


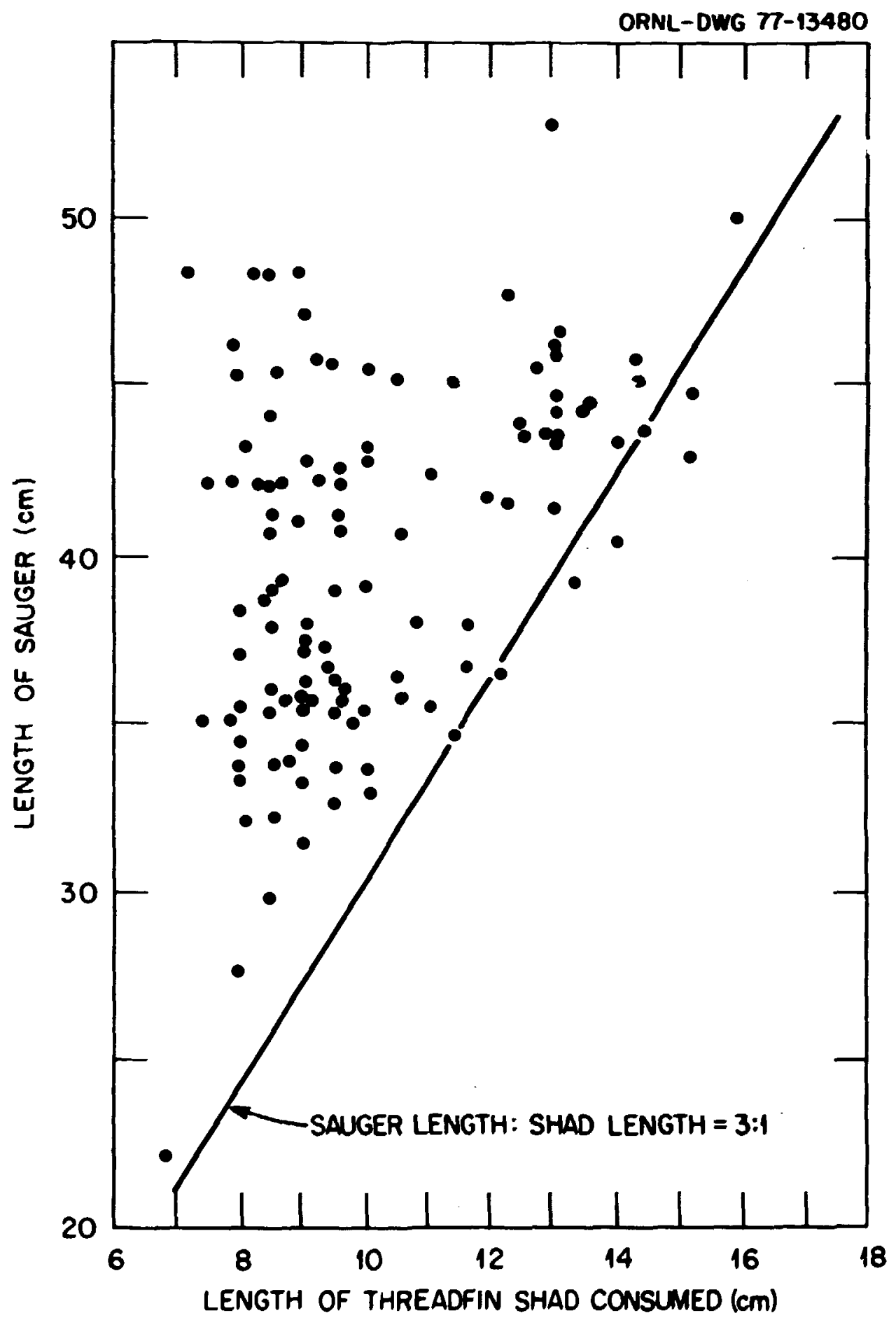

Figure 6. Length distribution of threadfin shad consumed by sauger, from November 1976 through February 1977. The line represents a hypothetical $3: 1$ ratio of predator length to maximum prey length which could be consumed. 


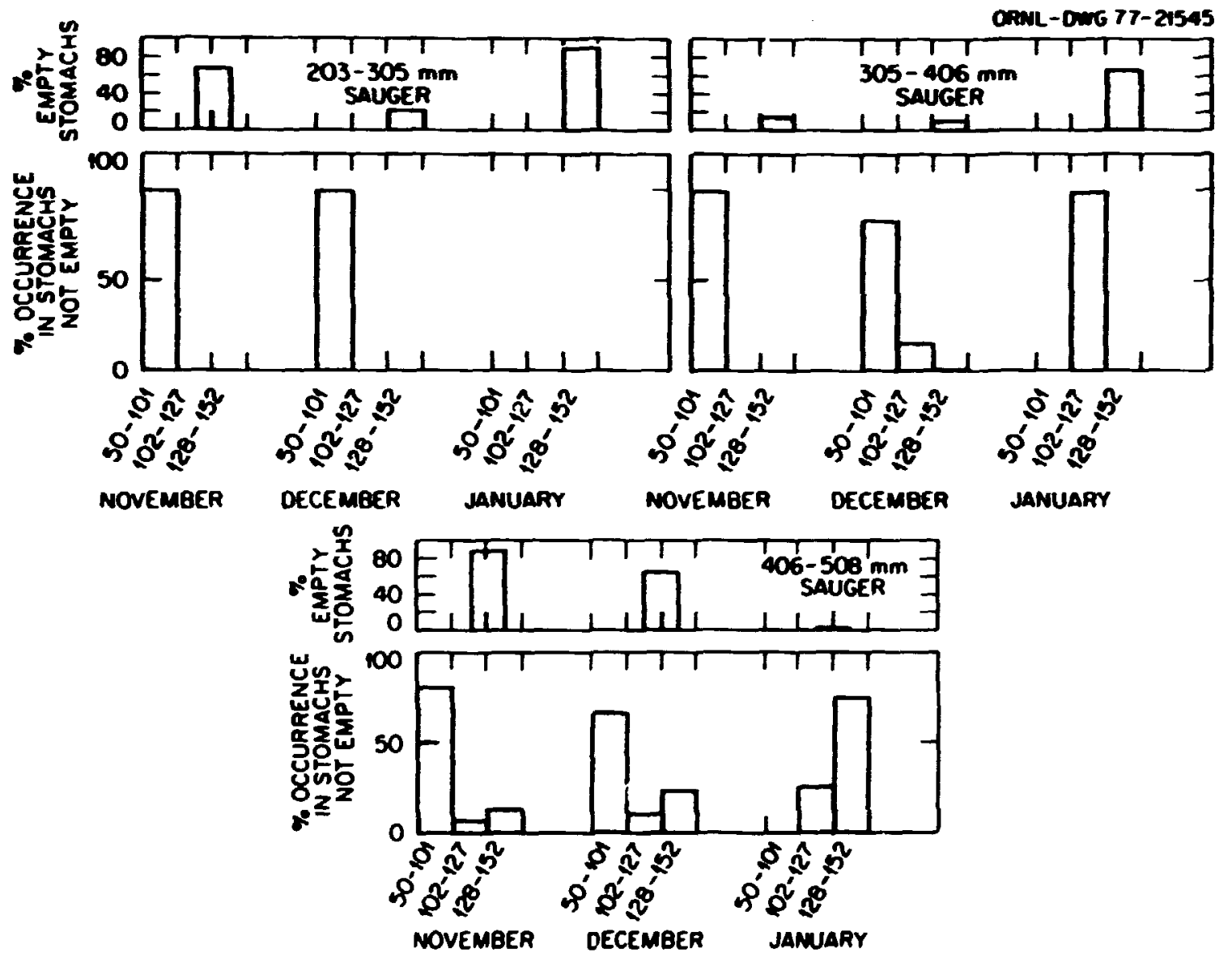

Figure 7. Percent occurrence by size class of threadfin shad, Dorosoma petenense, in stomachs of three size classes of sauger, Stizostedion canadense, during November, 1976 through January, 1977. 
lengths of sauger from 22 to $50 \mathrm{~cm}$ long and approximated a $3: 1$ ratio of predator to maximum prey lengths (Fig. 6).

Visceral Fat Content of Sauger

Sauger stored excess energy available to them in visceral fat reserves comprising 1 to $9 \%$ of body wight. Fat content, expressed as mg fat/g body weight, increased with increasing length of sauger (Table 4) and was influenced by sex and maturity. Inmature sauger less than $30 \mathrm{~cm}$ contained the least amounts of visceral fat, wile sauger over $40 \mathrm{~cm}$, primarily mature males and females, contained the largest fat reserves. Most sauger retained some stores of visceral fat through the winter, though quantities were reduced in April.

\section{RESULTS: DIGESTION RATE STUDIES}

\section{Effect of Temperature on Digestion}

Results of laboratory digestion experiments quantified the effect of temperature on the digestion rates of sauger at 5,10 , and $15 \mathrm{C}$. The mean percent digestions of force-fed meals of 4 to $7 \mathrm{~g}$ fathead mimows by sauger after 6,12, 18, and $24 \mathrm{hr}$ at each exper imental temperature are presented in Table 5. These data sumarize multiple observations made on all sauger in each experimental group, and indicate the retarding effect of temperature on digestion. Slopes of the regression line calculated for individual sauger at each temperature indicate the rates of digestion increased with increasing temperature but not in direct proportion to temperature (Table 6). An increase of $5 \mathrm{C}$ between 10 and $5 \mathrm{C}$ had a greater effect on digestion then that between 5 and $10 \mathrm{C}$ 
TABLE 4

Mean fat content, expressed as $\mathrm{mg}$ fat/g body weight, of 3 size classes of sauger indicating the general relationship between length and visceral fat reserves. The range of values, standard deviation of means and sample size for each group are also presented.

\begin{tabular}{lccc}
\hline & \multicolumn{3}{c}{ Size class of sauger $(\mathrm{cm})$} \\
\cline { 2 - 4 } Mean & $20.0-30.0$ & $30.1-40.0$ & $40.1-50.0$ \\
S.D. & 2.6 & 3.6 & 6.3 \\
Range & 1.6 & 2.3 & 2.1 \\
N & $1-5$ & $1-9$ & $4-9$ \\
& 8 & 42 & 8 \\
\hline
\end{tabular}


TABLE 5

Mean percent digestion of force-fed meals of fathead minnows by sauger at 5,10 , and $15 \mathrm{C}$. Number of observations are in parenthesis. Standard deviations of means are included (S.D.).

\begin{tabular}{|c|c|c|}
\hline \multirow{2}{*}{$\frac{\begin{array}{c}\text { Temperature and } \\
\text { Duration }(\mathrm{hr})\end{array}}{\underline{5 \mathrm{C}}}$} & \multicolumn{2}{|c|}{$\begin{array}{c}\text { Meai Size } \\
10-20 \mathrm{mg} \mathrm{Food} / \mathrm{g} \text { Sauger }\end{array}$} \\
\hline & Mean & S.D. \\
\hline 6 & $8.2(6)$ & 4.2 \\
\hline 12 & $19.8(13)$ & 5.9 \\
\hline 18 & $32.5(16)$ & 10.2 \\
\hline 24 & $38.8(16)$ & 7.7 \\
\hline \multicolumn{3}{|l|}{$10 \mathrm{C}$} \\
\hline 6 & $10.8(6)$ & 3.2 \\
\hline 12 & $19.9(15)$ & 6.6 \\
\hline 18 & $39.3(11)$ & 5.3 \\
\hline 24 & $43.5(8)$ & 6.6 \\
\hline \multicolumn{3}{|l|}{$15 \mathrm{C}$} \\
\hline 6 & $19.1(7)$ & 9.8 \\
\hline 12 & $35.2(16)$ & 5.6 \\
\hline 18 & $77.3(16)$ & 9.1 \\
\hline 24 & $83.0(16)$ & 9.6 \\
\hline
\end{tabular}


TABLE 6

Slope coefficients of regression calculated for individual sauger at 5,10 , or $15 \mathrm{C}$. These slopes were used to determine mean digestion rates at each temperature. $R^{2}$ values and standard errors are included for each regression.

\begin{tabular}{|c|c|c|c|c|c|c|c|c|c|c|c|}
\hline \multicolumn{12}{|c|}{ Temperature } \\
\hline \multicolumn{4}{|c|}{$5 C$} & \multicolumn{4}{|c|}{$10 \mathrm{C}$} & \multicolumn{4}{|c|}{$15 \mathrm{C}$} \\
\hline Fish & Slope & S.E. & $\mathbf{R}^{2}$ & Fish & Slope & S.E. & $\mathbf{R}^{2}$ & Fish & Slope & S.E. & $\mathbf{R}^{2}$ \\
\hline 1 & 1.82 & 0.16 & 0.97 & 9 & 2.00 & 0.12 & 0.99 & 17 & 3.51 & 0.24 & 0.97 \\
\hline 2 & $1 . \leqslant 2$ & 0.27 & 0.86 & 10 & 1.56 & 0.25 & 0.91 & 18 & 3.70 & 0.15 & 0.99 \\
\hline 3 & 2.03 & 0.17 & 0.96 & 11 & 2.05 & 013 & 0.95 & 19 & 3.94 & 0.32 & 0.96 \\
\hline 4 & 1.69 & 0.17 & 0.95 & 12 & 1.83 & 0.06 & 0.99 & 20 & 3.49 & 0.20 & 0.98 \\
\hline 5 & 1.56 & 0.10 & 0.98 & 13 & 1.64 & 0.36 & 0.83 & 21 & 3.59 & 0.26 & 0.97 \\
\hline 6 & 1.78 & 0.13 & 0.97 & 14 & 1.96 & 0.14 & 0.97 & 22 & 3.37 & 0.24 & 0.97 \\
\hline 7 & 1.39 & 0.14 & 0.91 & 15 & 2.01 & 0.15 & 0.96 & 23 & 3.60 & 0.26 & 0.97 \\
\hline 8 & 1.49 & 0.12 & 0.98 & 16 & c. 36 & 0.23 & 0.96 & 24 & 3.96 & 0.32 & 0.96 \\
\hline Mean & 1.67 & & & & 1.93 & & & & 3.65 & & \\
\hline
\end{tabular}


(Fig. 8). As determined from these experiments digestion of a 4 to $7-9$ meal by sauger can occur 1.89 times faster at $15 \mathrm{C}$ than an equivalent meal at $10 \mathrm{C}$, and 2.18 times faster than one at $5 \mathrm{C}$. The magnitude of the differences in the digestion rate between 5 and $15 \mathrm{C}$ would appear to satisfy the relationship described by van't Hoffs law. This law states that for every $10 \mathrm{C}$ rise in temperature the rate of reaction is doubled, and has been applied to other studies of metabolic activities of fish (Andrews 1974).

\section{Effect of Food Type on Digestion}

Digestion rate experiments using threadfin shad as the food source were limited by the availability of fresh shad of the proper size during the experimental period. Enough shad were obtained, however, to parmit several observations of the digestability of threadfin to be made. Percent digestion by sauger force-fed meals of threadfin shad were calculated after 12, 18, anc $24 \mathrm{hr}$. Sauger digested these meals slightly faster than equivalent meals of fathead minnows. Mean percent digestion of threadfin shad by sauger held at 5 and $10 \mathrm{C}$ are presented in Table 7. Greater variability in results and fever numbers of observations reduced the value of these data in predicting digestion rates of force-fed meals of threadfin shad.

\section{Effect of Force-Feeding}

Results of 30 paired observations on sauger held at $15 \mathrm{C}$ over a wide $r$ ange of meal sizes $(3.3-65.2 \mathrm{mg} / \mathrm{g})$ indicated no significant difference in digestion after $8 \mathrm{hr}(T$-test $P<0.05)$. Mean percent differences between digestion of force-fed and voluntarily consumed meals 


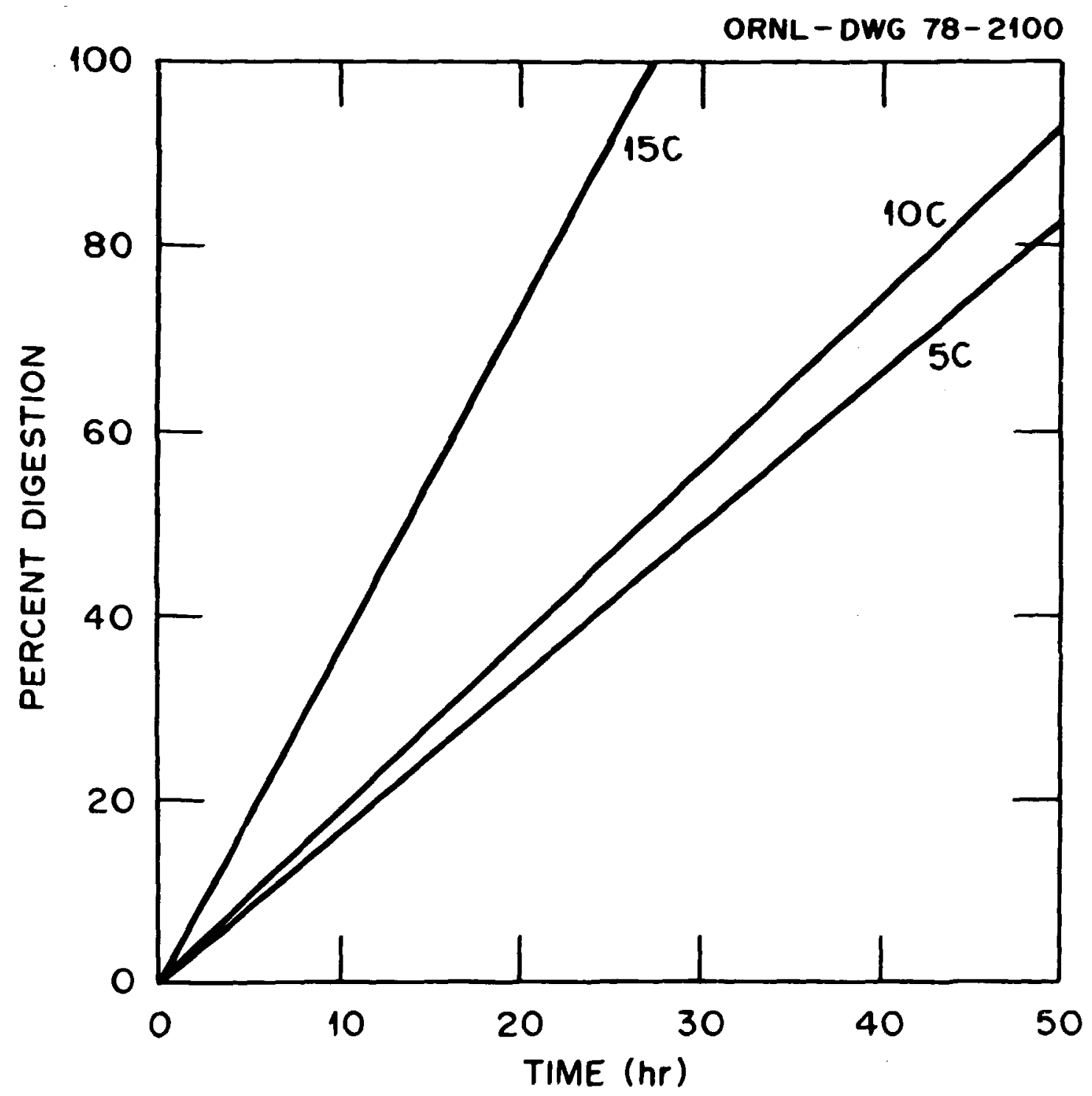

Figure 8. Mean slopes of calculated regression equations describing the digestion rate for individual sauger at 5, 10, or $15 \mathrm{C}$. Sauger were forcefed 4-7 $g$ meals of fathead minnows. 
TABLE 7

Mean percent digestion by sauger of force-fed meals of threadfin shad at 5 and $10 \mathrm{C}$. Number of observations is in parenthesis. Standard deviations of means are included (S.D.).

\begin{tabular}{|c|c|c|}
\hline $\begin{array}{l}\text { Temperature and } \\
\text { Duration (hr) }\end{array}$ & \multicolumn{2}{|c|}{$10-30 \mathrm{mg}$ Food/g Sauger } \\
\hline $5 c$ & Mean & S.D. \\
\hline 12 & $31.8(7)$ & 5.3 \\
\hline 18 & $35.2(6)$ & 14.5 \\
\hline 24 & $39.5(8)$ & 8.8 \\
\hline \multicolumn{3}{|l|}{$10 \mathrm{C}$} \\
\hline 12 & $28.0(10)$ & 5.7 \\
\hline 18 & $51.0(5)$ & 3.4 \\
\hline 24 & $44.0(5)$ & 11.5 \\
\hline
\end{tabular}


34

for each group however were consistently negative (Table 8) and indcoated a nonsignificant reduction in digestion using the force-feeding method. Use of the force-feeding method was considered accurate enough to estimate digestion rates of sauger at similar temperatures in Watts Bar Reservoir. 
TABLE 8

Mean percent differences in digestion of force-fed and voluntarily consumed meals by sauger held at $15 \mathrm{C}$. Sauger consuming similarly sized meals are grouped by meal size expressed as mg food/g sauger.

\begin{tabular}{ccccc}
\hline $\begin{array}{c}\text { Meal Size } \\
\text { mg Food/g Sauger }\end{array}$ & $\begin{array}{c}\text { Mean Percent } \\
\text { Difference } \\
\text { in Digestion }\end{array}$ & $\begin{array}{c}\text { Standard } \\
\text { Deviation }\end{array}$ & $\begin{array}{c}\text { Standarc } \\
\text { Error }\end{array}$ & N \\
\hline 10 & -1.50 & 12.63 & 4.46 & 8 \\
$10-20$ & -3.25 & 7.17 & 2.53 & 8 \\
$20-30$ & -5.00 & 7.33 & 2.77 & 7 \\
-30 & -1.25 & 9.43 & 4.71 & 4 \\
\hline
\end{tabular}


CHAP TER IV

DISCUSSION

Prey Selection by Sauger as Related to Impingement and Mortality of Threadf in Shad

Threadfin shad were the most important prey species utilized by sauger and occurred as the only food positively identified from stomachs from Novenber to January. At least four species of alternate prey were ut ilized after, but not before, depletion of the threadfin populations in January, indicating threadfin were the preferred prey of sauger (probably because of thæir relative abundance and vulnerability). Walleye in Lake Erie exhibited a similar preference for the most abundant prey of acceptable size when large numbers of forage species were availahle (Parsons 1971). Sauger did not appear to be selective for alternate prey which were utilized.

Records of fish impingement at the Kingston Steam Plant during the study period indicate striking changes in impingement of threadfin shad with time and temperature (Fig. Al, Appendix), which can be related to changes in sauger food consumption. In November and December 1976, impingement averaged several thousand per day, peaking in mid-December at over 42,000 in $24 \mathrm{hr}$. Differences existed in the size classes of threadfin impinged through time (Fig. A2, Appendix), and suggest an increased cold tolerance of the larger individuals. This differential survival affected the size range of threadfin available to and utilized by sauger throughout the winter (Fig. A3, Appendix). Impingement declined rapidly in late December and early January while water 
temperatures remained low, probably indicating depletion of the population in the vicinity of the canal. Continued cold weather and low water temperature in January resulted in cold-induced mortalities of threadfin at other saripi? sites, as evidenced by gill net catches and observations of threadfin dying in coves. Hith the exception of a small population in the discharge canal, probably very few threadfin survived the winter (Griffith et al. 1977).

After the decline of threadfin populations in January, sauger consumed alterilate prey in approximately the same proportion as these species were impinged on intake screens (Fig. A4, Appendix). Threadf in shad utilized in February had a higher percent occurrence in sauger stomachs than on intake screens, suggesting continued selection by sauger for the remaining threadfin. It is interesting to speculate on the possibility that intake screens could provide a sensitive index of prey availability to sauger. The highest impingement counts for threadf in occurred during the months of greatest sauger predation on this species, indicating the relationship of cold stress to vulnerability to impingement, and to predation, as previously determined by laboratory experiments (Griffith and Tomijanovich 1975, Griffith 1978). Most sauger moved out of the intake canal after December, when impingement counts indicated depletion of the threadfin population at this site. Sizes of threadfin consumed by sauger increased with sizes of impinged threadfin as the smaller size classe: became unavailable due to cold-induced mortality. The decline in sauger predation on threadfin and a dramatic increase in the number of empty stomachs followed approximately two weeks behind the drop in numbers of impinged threadfin, both indicating 
the depletion of threadfin populations due to cold-induced mortality. These relationships wich existed provide evidence for the use of impingement monitoring as an index of the abundance and vulnerability of forage species, but also suggest a possible "competition" could exist between intake screens and sauger for these vulnerable prey. Food consumption by sauger was not directly limited by impingement-related mortality of threadfin shad, except perhaps in the vicinity of the intske canal, but was reduced in winter due to the combined effects of natural cold-induced mortality, predation, and impingement.

\section{Application of Digestion Rate Studies}

Use of mean-calculated regression coefficients for digestion rates allows estimates of the time required for digestion of meals by sauger during the winter months. For sauger consuming meals of 4 to $7-g$ threadfin shad (approx. $8-10 \mathrm{~cm}$ in length) at temperatures between 5 and $10 \mathrm{C}$, digestion could reach $90 \%$ completion in approximately 47 to $54 \mathrm{hr}$. At $15 \mathrm{C}$, digestion would require approximately $25 \mathrm{hr}$ to reach $90 \% \mathrm{com}$ pletion. Digestion of meals beyond this point, termed the residual phase (Windell 1966), consists primarily of dissolution of resistant parts and was not included in this analysis.

Other factors influencing digestion may reduce the accuracy of these est imates. In st udies with walleye and sauger at 14.5 and $20 \mathrm{C}$, Swenson and Smith (1973) found food digested per hour increased with meal size and fish size. Later Swenson (1977) concluded that high stamach volumes tended to compensate for the effects of low temperature $(14.5 \mathrm{C})$ on digestion. If these effects continue to operate at 5 and 
$10 \mathrm{C}$, digestion by sauger consuming meals of multiple shad during the winter months in Hatts Bar Reservoir may proceed more rapidly than est $i$ mated by the exper imental methods.

In experiments to determine the influence of a substitute food source on the digestive rate, sauger digested meals of threadfin shad slightly faster than equivalent meals of fathead min-ows. This slight increase may be due to the fact that regressions on threadfin data were calculated only from observation after 12,18 , and $24 \mathrm{hr}$, as opposed to observation after $6,12,18$, and $24 \mathrm{hr}$ for digestion of fatheads. By ignoring the lag time which exists in the early stages of digestion these regressions describing digestion of threadfin by sauger may be slightly overestimating the rate and may account for the observed increase. Swenson and Smith (1973) found slight differences in digestability of yellow perch and fathead minnows, but concluded that use of fatheads as a substitute food source did not significantly reduce accuracy of estimates of the digestion rate for walleye and sauger.

Digestion of force-fed meals by sauger was consistently less than that of voluntarily consumed meals over a wide range of meal sizes but was not significantly reduced in any case. Results from another study (Swenson and Smith 1973) indicated force-feeding of walleye significant ly reduced digestion after $8 \mathrm{hr}$ at $14.5 \mathrm{C}$. Data from the present study suggest that the bias introduced by force-feeding may not be as great. The slight reduction in digestion could be due to the lack of a feeding stimulus preceding ingestion of the meal, or to the effects of the anestivetic $\mathrm{AS}-222$, or to handing stress. If force-feeding exerts a continuous influence throughout the time required for complete digestion 
then perhaps digestion could be significantly reduced. It does not seem likely the effect would act in this manner, and force-feeding was not considered a source of significant error in these exper iments. Any bias that was introduced by force-feeding would suggest that digestion of meals consumed by sauger in Hatts Bar Reservoir within the temperature ranges considered could proceed faster then predicted from these experiments.

\section{Utilization of Food Energy}

The high proportion of sauger stomachs containing shad, coupled with laboratory est imates of the digestive rate, suggest that food consumption in late fall and winter was sufficient to result in quantities of excess energy available to sauger. In caloric energetic studies of walleye maintenance requirements and conversion and assimilation efficiencies, Kelso (1972) determined energy for maintenance was similar between 4 and $12 \mathrm{C}$, but increased rapidly above this point. Gross and net conversions were not affected by temperature and assimilation efficiency was high. Conversion of energy for growth was low at lower temperatures and growth did not occur at temperatures below $12 \mathrm{C}$. Walleye underwent a pronounced seasonal change in energy content and the caloric accumulation was stored in interstitial and abdominal fat deposits (Kelso 1973). The seasonal change in biocontent was judged to represent a significant contribution to the energy budget of walleye.

Similar changes in bioenerget ic content of sauger would be expected to occur. Growth of sauger and walleye does not occur during the winter months in Tennessee and food consumption in winter results in 
accumulation of large visceral fat reserves (Dendy 1946a, Hassler 1953, Stroud 1949). Sauger examined in the present study contained fat reserves comprising approximately 1 to $9 \%$ of bcdy weight. Larger mature sauger had proportionally more energy stored in fatty tissues; immature sauger less than $30 \mathrm{~cm}$ contained the least anount of fat reserves.

Energy stored in tissues and available directly from food consumed in winter was probably important to sauger for gonadal development and ma intenance requirements in late winter and spring when food consumption was reduced. The principal growth phase of ovaries in Stizostedion and Perca spp. takes place during the coolest seasons when body growth ceases (Hokanson 1977). Insufficient fat reserves to meet energetic demands of cogenesis and winter maintenance requirements increased mortality of female yellow perch in two Laurentian lakes (Newsome and Leduc 1975). Deficiency in food and poor growth conditions in summer have also caused missed spawing periods and oocyte resolution in Stizostedion SPP. (Forney 1965, Eschmeyer and Smith 1943). Successful spawning and good growth of sauger during the spring and summer of 1977 indicate that $f$ at reserves probably were utilized and were important in maintaining healthy conditions of the sauger population (McGee, unpublished data).

The importance of late fall and winter feeding by sauger on threadfin shad can also be considered in terms of the seasonal abundance and distribution of threadfin. As a semi-tropical planktivorous species, threadfin shad prefer the warmest temperatures available, and are found primarily in littoral and epipelagic zones throughout the summer. Shad in Norr is Reservoir, Tennessee, were most abundant in surface waters at 
a temperature $r$ ange of 21 to 27 C through sumer (Dendy 1946b). In th is same study sauger were found to prefer deeper strata with a temperature range of 15.5 to $21.0 \mathrm{C}$ and were concentrated just above layers of water with low oxygen content. These differences in the preferred temperatures of the sauger and threadfin shad suggest that, in sumer, sauger may at times be spatially isolated from threadfin, and that this factor could reduce food consumption. Behavioral characteristics of the two species may aid in mitigating this effect on the predator-prey interaction. Diel migration in depth distribution of threadfin shad occurs (Netsch et al. 1971) and may increase spatial over lap in the distribution of the two species during the $n i g h t$. Crepuscular and nocturnal feeding forays of sauger into warmer waters would also increase interaction.

High water temperatures increased maintenance requirements and cyclic changes in water temperature lowered food conversion of walleye (Kelso 1972). Spatial isolation between gizzard shad and walleye due to temperature preferences decreased availability of shad and resulted in a reduced growth rate of older walleye in Hoover Reservoir, Ohio (Momot et al. 1977). Similar effects would increase the energetic costs of sauger predation on threadfin and reduce the predatory efficiency of sauger during the jummer months. Sauger and walleye exhitit similar physiological optimum temperatir: ranges, and lower temperatures required for walleye spawning are the principal difference between the twc species (Hokanson 1977).

Because of the adaptations of sauger to a cool-water, low-light environment, optimal feeding conditions should occur in late fall and 
winter as water temperatures cool, becoming more uniform throughout and as young-of-the-year shad become stressed. Shorter daylengths in fall and winter months increase the total hours of twilight and darkness during which sauger are more efficient predators (Ryder 1977). Data from this study suggest that for several months in late fall and winter, predation by sauger on threadfin shad was facilitated by a combination of these factors.

Destabilizing Effects of Cold-induced Threadf in Shad Mortality

Cold-induced threadfin shad mortality, as determined by this study, reduced food consumption by sauger and increased predation on at least four species of alternate prey in late winter and spring. Increased predation on alternate prey suggests that threadfin shad acted as a buffer, reducing sauger predation on other species, while threadf in remained available. Conversely it may be argued that predation on alternate prey acted as a buffer, relieving predation pressure on depleted threadfin stocks. The role of a buffer species, however, has usually been assigned to the most abundant prey species. A high density of yellow perch was suggested to act as a buffer, reducing walleye predation on other forage species in One ida Lake, New York (Forney 1974). Alewives acted as a buffer, reducing predation on yellow perch and alternate prey in Lake Michigan (Wagner 1972). The high percentage of empty sauger stomachs in late winter, after loss of the forage base provided by threadfin, suggests that alternate prey were not utilized as heavily by sauger due to unavaliability or continued selectivity for the remaining threadfin. Under these circumstances it seems reasonable to 
say that alternate prey relieved predation pressure on threadfin only after threadfin reached a critical minimum density, or unavailability due to larger size of surviving individuals, and these alternate prey were utilized only in approximate proportion to the ir vulnerability and abundance. Threadfin, however, were preferred and selected for by sauger while they remained abundant and vulnerable, and for this reason they acted as a buffer for the alternate prey which were presumably available to sauger throughout the study.

Ability of threadfin shad to compensate for the severe reduction in numbers incurred during winter 1977 may be most important in determining possible long-range impacts on sauger growth rate and fecundity. A winter mortality of gizzard shad appeared to be responsible for a decline in the growth rate of sauger in Lew is and $\mathrm{Clark}$ Lake, South Dakota (Nelson 1969). Lack of for age fish in some years was considered a factor 1 imiting the growth rate of sauger from Lake Winnebago, Wisconsin (Priegel 1969).

Data collected during late sumer and fall 1977 indicate that compensation by surviving threadfin shad was sufficient to successfully reestablish this species in Watts Bar Reservoir (Griffith et al., unpublished data). In view of the severity of the winter 1977 , these data suggest that established populations of threadfin shad are capable of surviving winters in Tennessee despite extensive cold-induced mortality. scale reading of sauger collected in late fall 1977 and winter 1978 indicated growth rate of sauger in 1977 in Watts Bar Reservoir was proportional to that in previous years and that the magnitude of 
threadfin shad mortality in winter had an unpronounced effect on sauger growth (McGee and McLean, unpublished data).

Important aspects of the predator-prey relationship of sauger and threadfin shad which can be suggested for further study include seasonal changes in energy content of sauger as influenced by food consumption, spatial and temporal restrictions on sauger-threadfin interactions in sumner, and relationships between fish impingement and predation on these species by sauger. 


\section{CHAP TER V}

\section{SUMARY}

1. Threadfin shad were the only positively identified species utilized as food by sauger from Novembre 1976 to January 1977.

2. Sauger utilized threadfin because they were the most abundant and vulnerable prey species of the preferred size available.

3. Cold-induced behavioral changes in threadfin below approximately $10 \mathrm{C}$ reduced swimming abilities and increased vulnerability to predation and impingement.

4. The maximum lengths of shad consumed by sauger approximated a 3 to 1 predator-to-prey ratio and influenced the availability of threadfin to sauger.

5. Predation on threadfin by sauger less than $30 \mathrm{~cm}$ in length was limited by the availability of threadfin less than 8 to $10 \mathrm{~cm}$.

6. Sauger over $42 \mathrm{~cm}$ in length could utilize yearling and older threadfin 12 to $15 \mathrm{~cm}$ in length. Mature female sauger were more abundant than males in the size classes of sauger able to utilize the larger threadfin shad.

7. Extensive cold-induced mortality of threadfin in December and January reduced sauger food consumption and increased predation on freshwater orum, logperch, bluegills, mayfly nymphs, and other unidentified prey species.

8. Gizzard shad were never positively identified from sauger stomachs and gizzard shad of a size avallable to sauger were not abundant during the study period. 
9. Sauger appeared to store excess energy available at low temperatures as visceral fat reserves comprising approximately 1 to $9 x$ body wight. Fat content was greatest in larger mature sauger. Sauger under $30 \mathrm{~cm}$ contained the least amounts of visceral fat.

10. Laboratoy digestion rate experiments determined digestion of a 4 to ?-g meal by sauger required approximately $54 \mathrm{hr}$ at $5 \mathrm{C}, 47 \mathrm{hr}$ at $10 \mathrm{C}$, and $25 \mathrm{hr}$ at $15 \mathrm{C}$ to reach 906 completion.

11. Comparison of digestion of force-fed and voluntarily consumed meals by sauger indicated no significant difference in digestion (T-test $P<0.05$ ) using the force-feeding method. 


\section{BIBL IOGRAPHY}

Aggus, L. R. 1973. Food of angler harvested largemouth, spotted, and smallmouth bass in Bull Shoals Reservoir. Proc. S. E. Assoc. Game and Fish Comm. 26:501-505.

Ali, M. A., R. A. Ryder, and M. Anctil. 1977. Photoreceptors and $v$ isual pigments as related to behavioral responses and preferred habitats of perches (Perca Spp.) and pikeperches (Stizostedion spp.). J. Fish. Res. Board Can. 34:1475-1480.

Andrews, J. H., and Y. Matsuda. 1975. The influence of various culture conditions on the oxygen consumption of channel catfish. Trans. An. Fish. Soc. 104:322-327.

Brett, J. R., and D. A. Higgs. 1976. Effect of temperature on the rate of gastric digestion in finger ling sockeye salmon, Oncorhynchus nerka. J. Fish. Res. Board Can. 27:1767-1779.

Carlander, K. D. 1950. Growth rate studies of saugers, Stizostedion canadense canadense (Smith) and yellow perch, Perca flavescens (Mitchill) from Lake of the Woods, Minnesnta. Trans Am. Fish. Soc. $79: 30-42$.

Carter, N. E. 1968. Age and growth of sauger in Pool 19 of the Mississippi river. Iowa Acad. Sci. 75:179-183.

Carufel, L. H. 1963. Life history of saugers in Garrison Reservoir. J. Wildl. Manage. 27:450-456.

Dendy, J. S. 1946a. Food of several species of fish, Norris Reservoir, Tennessee. J. Tenn. Acad. Sci. 21:105-127. 
Dendy, J. S. 1946b. Further studies of depth distribution of fish, Norris Reservoir, Tennessee. J. Tenn. Acad. Sci. $21: 94-104$.

Dryer, H., and N. G. Benson. 1957. Observations on the influence of the New Johnsonville Steam Plant on fish and plankton populations. Proc. S. E. Asscc. Game and Fish Comm. 10:85-91.

Eschmeyer, R. H., and C. G. Smith. 1943. Fish spawning below Norr is Dam. J. Tenn. Acad. Sci. 18:4-5.

Forney, J. L. 1965. Factors affecting growth and maturity in a walleye population. N.Y. Fish. Game J. 12:217-232.

Forney, J. L. 1974. Interactions between yellow perch abundance, walleye predation, and survival of alternate prey in Oneida Lake, New York. Trans. An. Fish Soc. 103:15-24.

Galligan, J. P. 1960. Winter food habits of pikeperch in Oneida Lake. N.Y. Fish Game J. 7:156-157.

Griffith, J. S. 1978. Effects of low temperature on the behavior and survival of threadfin shad, Dorsoma petenense. Trans. Am. Fish. Soc. 107:63-69.

Griffith, J. S., and D. A. Tomljanovich. 1975. Susceptibility of threadfin shad to impingement. Proc. S. E. Assoc. Game and Fish Comm. 29:223-234.

Griffith, J. S., R. B. McLean, and R. W. Pasch. 1977. Ecological effects of cold-induced mortality and impingement of threadfin shad Dorsoma petenense. Abstract Symp. of tile Savannah River Ecol. Lab. 
Hart, J. L. 1928. Data on the rate of growth of pikeperch,

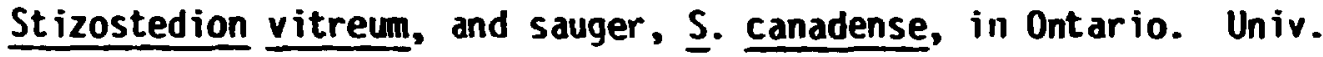
Toronto Stud., Biol. Ser. No. 31, Publ. Ont. Fish. Res. Lab. 34 : 45-55.

Hassler, H. W. 1953. Age and growth of the sauger, Stizostedion Canadense canadense (Smith), in Norr is Reservoir, Tennessee. Ph. D. dissertation. University of Tennessee, Knoxville, Tennessee. 171 p.

Hokanson, K. E. F. 1977. Temperature requirements of some percids and adaptations to the seasonal temperature cycle. J. Fish. Res. Board Can. 34:1524-1550.

Hubbs, C. 1951. Minimum temperature tolerances for fishes of the genera Signalosa and Herichthys in Texas. Copeia 4:297.

Ihrie, D. H. 1970. Food habits of the threadfin shad, Dorsoma petenense (Gunther), in Dale Hollow Reservoir, Tennessee. MS Thesis, Tenn. Tech. Univ., Crossville, Tennessee. 45 pp. Keast, A. 1968. Feeding of some Great Lakes fishes at low temperatures. J. Fish. Res. Board Can, 25:1199-1218.

Kelso, J. R. M. 1972. Conversion, maintenance, and assimilation for walleye, Stizostedion viteum vit,reum, as affected by size, diet, and temperature. J. Fish. Res. Board Can. 29:1181-119?.

Kelso, J. R. M. 1973. Seasonal energy changes in walleye and the ir diet in West Bluse Lake, Manitoba. Trans. An. Fish. Soc. $102: 363-368$. 
Lew is, H. M., R. Heidinger, H. Kirk, W. Chapman, and D. Johnson. 1974. Food intake of the largemouth bass. Trans. Am. Fish. Soc. $102: 277-280$.

Loar, J. M., J. S. Griffith, and K. Deva Kunar. An analysis of factors influencing the impingement of threadfin shad (Dorsoma petenense) at power plants in the southeastern United States. Proc. rourth National Horkshop on Entrainment and Impingement. Chicago, Illino is, December 5-7, 1977 (in press).

Markus, H. C. 1933. The extent to which temperature changes influence food consumption of the largemouth bass. Trans. Am. Fish. Soc. $62: 202-210$.

McGee, M. V., J. S. Griffith, and R. B. McLean. Prey selection by sauger as affected by cold-induced mortality of threadfin shad in Watts Bar Reservoir, Tennessee. Proc. S.E. Assoc. Fish and Wildl. Agencies 31 (in press).

McLean, R. B., J. Griffith, and M. McGee. 1978. Threadf in shad impingement: Effect of cold stress. Annual Report to the Nuclear Regulatory Comnission for Octobes 1, 1976 - September 30, 1977 from Enviromental Sciences Division, Oak Ridge National Laboratory, Oak Ridge, Tennessee.

Minckley, H. L., and L. A. Krumho1z. 1960. Natural hybridization between the clupeid genera Dorsoma and Signalosa with a report on

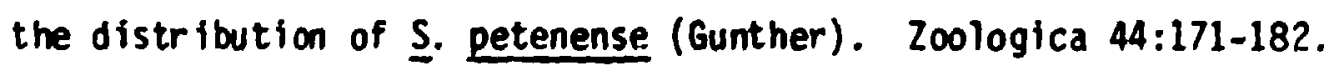


Molnar, Gy., E. Tamassy, and I. Tolg. 1966. The gastric digestion of living predatory fish. pp. 135-149. IN S. D. Gerking (ed.), The Biological Bas is of Freshwater Fish Production. John Wiley Sons Inc. Mew York. $495 \mathrm{pp}$.

Momot, H. T., J. Erickson, and F. Stevenson. 1977. Maintenance of a walleye Stizostedion vitreum vitreum, fishery in a eutrophic reservoir. J. Fish. Res. Board Can. 34:1725-1733.

Nelson, H. R. 1969. Biological characteristics of the sauger population in Lewis and Clark Lake. U.S. Bureau of Sport Fish and Hildl ife Tech. Paper 21.

Nelson, H. R., and C. H. Halburg. 1977. Population dynamics of yellow perch (Perca flavescens), sauger (Stizostedion canadense), and walleye ( $\underline{S}$. vitreum vitreum) in four main stream Missouri River reservoirs. J. Fish. Res. Board Can. 34:1748-1763.

Netsch, M. F., G. M. Kersh, A. Honser, and R. V. Kilambi. 1971. Distribution of young gizzard and threadin shad in Beaver Reservoir. Pp. 95-105. IN G. E. Hall (ed.), Reservoir Fisheries and Limnology. Am. Fish. Soc. Special Publ. 8.

Newsome, G. E., and G. Lizduc. 1975. Seasonal changes of fat content in the yellow perch, Perca flavescens, of two Laurentian lakes. J. Fish. Res. Board Can. 32:2214-2221.

Paloheimo, J. E., and L. M. Dickie. 1966. Food and growth of fishes. II. Effects of food and temperature on the relation between metabolisn and body weight. J. Fish. Res. Board Can. 23:869-908.

Parsons, J. W. 1971. Selective food preference of walleye of the 1959 year class in Lake Erie. Trans. Am. Fish. Soc. 100:474-485. 
Parsons, J. H., and J. B. Kimsey. 1954. A report on the Mississippi threadfin shad. Prog. Fish Cult. 16:179-181.

Pasch, R. H. 1974. Some relationships between food habits and growth of largemouth bass in Lake Blackshear, Georgia. Proc. S. $E$. Assoc. Game and Fish Comm. 28:307-321.

Popova, 0. A., and L. A. Sytina. 1977. Food and feeding relations of Eurasian perch, Perca fluviatilis, and pikeperch, Stizostedion lucioperca, in various waters of the USSR. J. Fish. Res. Board Can. $34: 1559-1570$.

Priegel, G. R. 1963. Food of walleye and sauger in Lake Mimebago, Wisconsin. Trans. Am. Fish. Soc. 92:312-313.

Priege1, G. R. 1969. The Lake Himebago sauger, age, growth, reproduction, food habits and early life history. Tech. Bull. 43. Department Natural Resources, Madison, Hisconsin. 63 pp.

Range, J. D. 1973. Growth of five species of game fishes before and after introduction of threadfin shad into Dale Hollow Reservoir. Proc. S. E. Assoc. Gine and Fish Comm. 26:510-517.

Ryder, R. A. 1977. Effects of ambient light variations on behavior of yearling, subadult, and adult walleye, Stizostedion vitreum vitreum. J. Fish. Res. Board Can. 34:1481-1491

Scott, E. M., Jr. 1976. Dynamics of the Center Hill walleye population. TWRA Tech. Rep. No. 76-55, Nashville, Tennessee. 86 pp.

Seaburg, K. G., and J. B. Moyle. 1964. Feeding habits, digestive rates, and growth of some Mimesota warmwater fishes. Trans. Am. F ish. Soc. 93:269-285. 
Sokal, R. R., and F. J. Rohlf. 1969. Biometry. H. H. Freeman and Co., San Francisco, California. 776 pp.

Swenson, W. A. 1977. Food consumption of walleye, Stizostedion vitreum vitreum, and sauger, $\underline{S}$. canadense, in relation to food availability and physical conditions in Lake of the Hoods, Mimesota, Shagawa Lake, and western Lake Superior. J. Fish. Res. Board Can. 34:1643-1654.

Swenson, H. A., and L. L. Smith, Jr. 1973. Gastric digestion food consumption, feeding periodicity and food conversion efficiency in walleye, Stizostedion vitreum vitreum, and sauger, $\underline{S}$. canadense, populations in Lake of the Hoods, Minnesota. J. Fish. Res. Board Can. $33: 1946-1954$.

Swenson, H. A., and L. L. Smith. 1976. Influence of food competition, predation, and cannabalism on walleye and group population in Lake of the Woods, Mimesota. J. Fish. Res. Board Can. 33:1946-1954.

Stroud, R. H. 1949. Rate of growth and condition of gane and panfish in Cherokee and Douglas reservoirs, Tennessee, and Hiwassee reservoir, North Carolina. J. Tenn. Acad. Sci. 24:60-74.

Hagner, H. C. 1972. Utilization of alewives by inshore picivorous fishes in Lake Michigan. Trans. Am. Fish. Soc. 101:55-63. Winde 11, J. T. 1968. Food analysis and rate of digestion. pp. 117-203. IN W. E. Ricker (ed.), Methods for the Assessment of Fish Production in Fresh Water. International Biol. Prog. Blackwell Sci. Publ., Oxford. 313 pp. 
Winde 11, J. T. 1966. Rates of digestion in fishes. PP. 151-173. AN S. D. Gerking (ed.), The Biological Basis of Freshwater Fish Production. John Wiley \& Sons Inc., New York. 495 pp.

Windell, J. T., D. O. Kitchell, D. O. Morris, J. S. Norris, and J. W.

Foltz. 1974. Temperature and rate of gastric evacuation by rainbow trout, Salmo gairdneri. Trans. Am. Fish. Soc. 105:712-717. 
$\because$

APPENDIX 



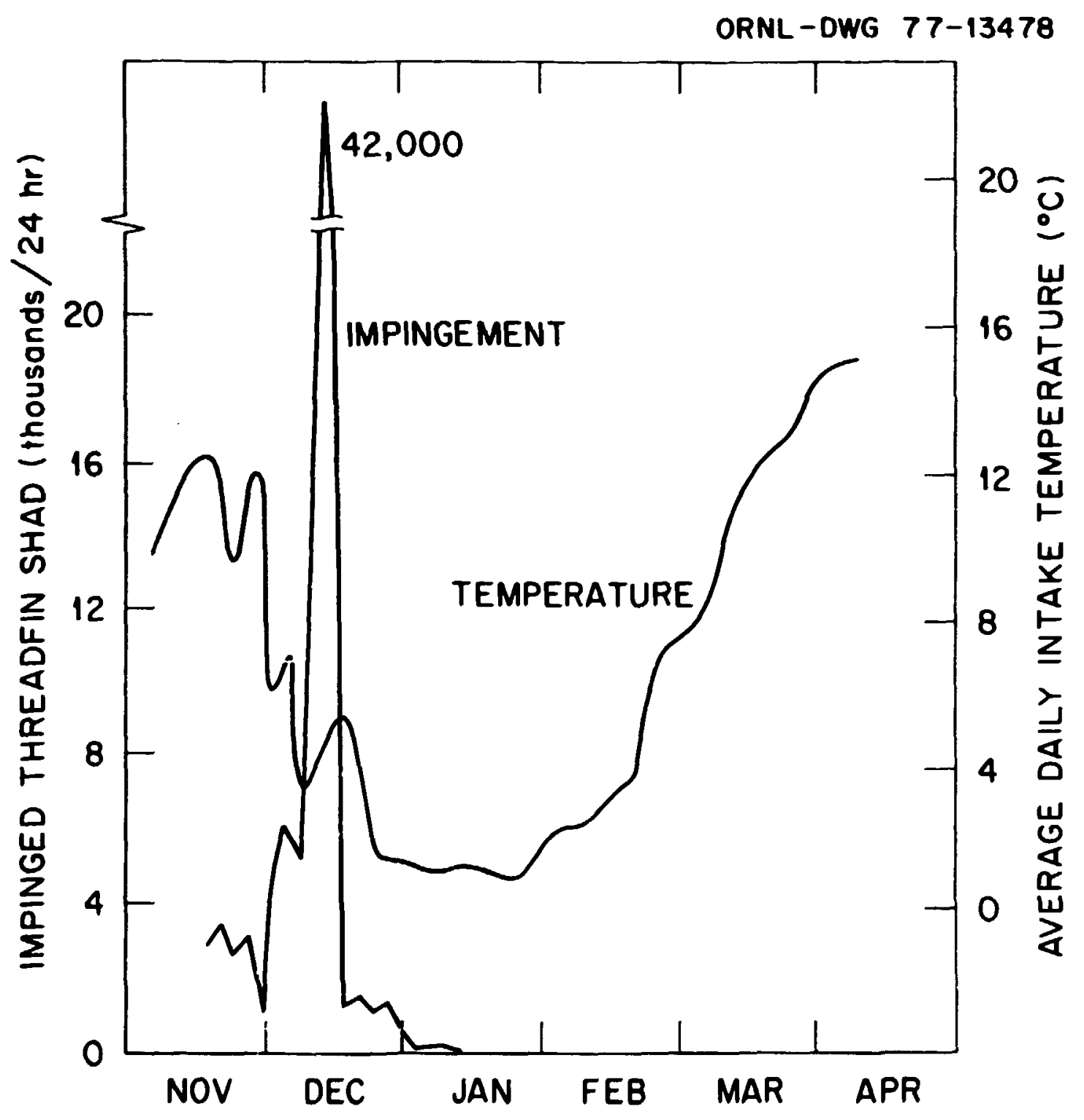

Figure Al. Impingement of threarfin shad at the Kingston Steam Plant: and water temperature in the intake canal from November 1976 through April $197 i$ (Source; McGee et al., in press). 


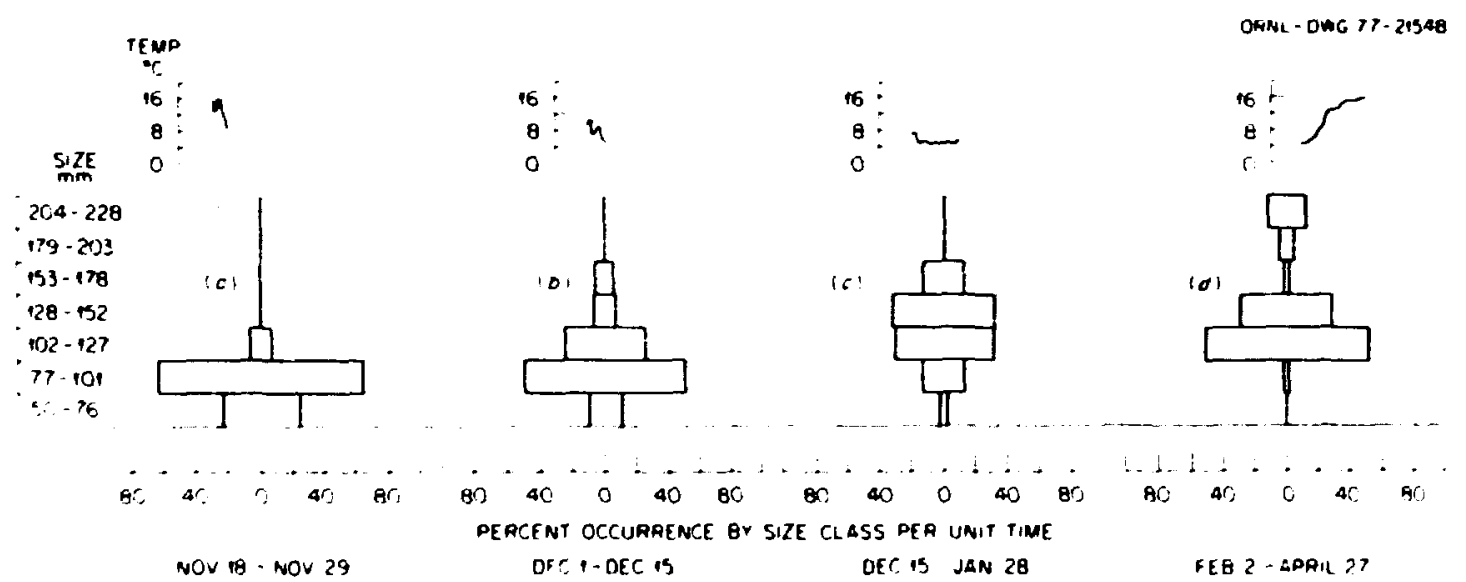

Figure A2. Percent occurrence by size class per unit time of threadfin shad, Dorosoma petenense, impinged at Kingston Steam PTant, Wat ts Bar Reservoir, Tennessee, November 1976 through April 27, 1977. (Source, McLean et a 1. 1378). 
Nov

SIZE $(\mathrm{mm})$

$153-180$

$128-152$

$102-127$

$77-101$

$50-76$
OEC

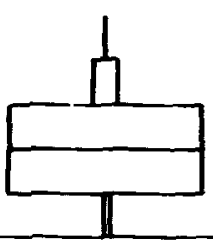

JaN

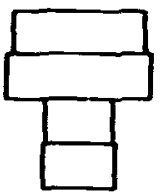

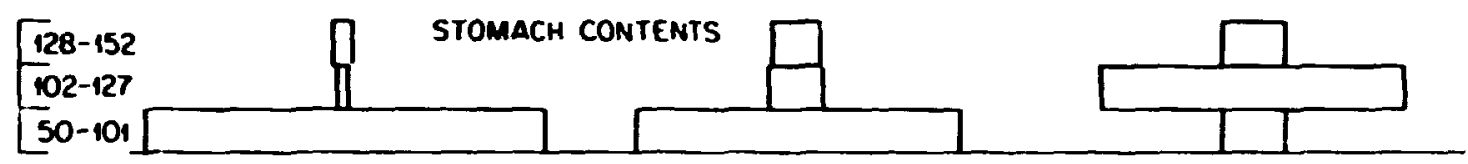

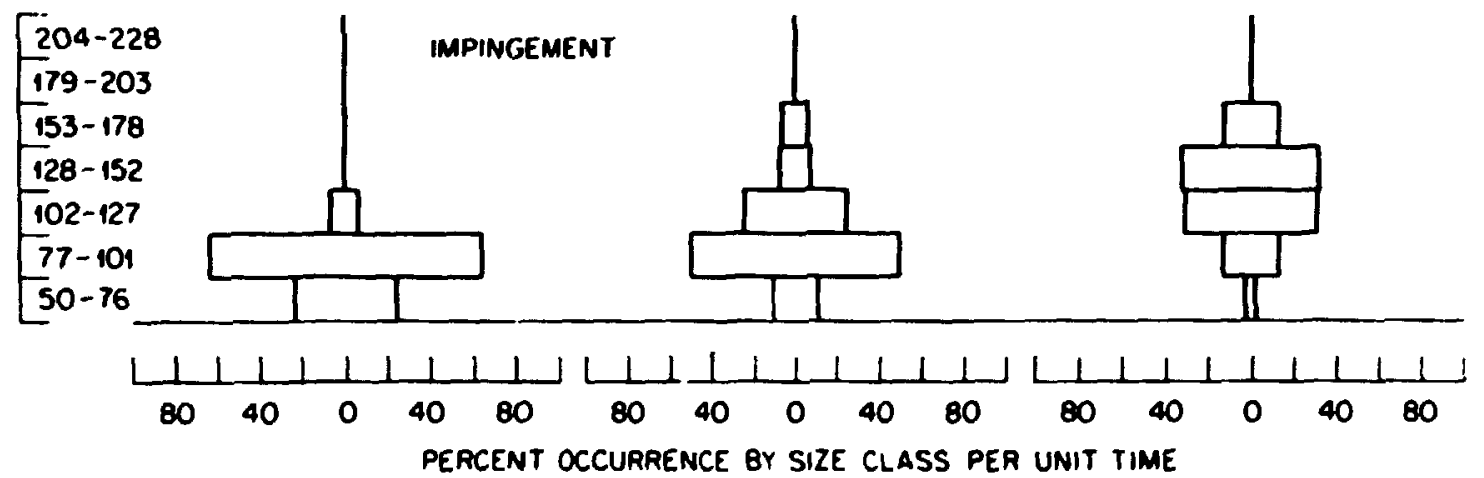

Figure A3. Comparison of size class distribution of threadfin shad collected on the intake screens, from sauger stomachs and in gill nets. (Source McLean et al. 1978). 


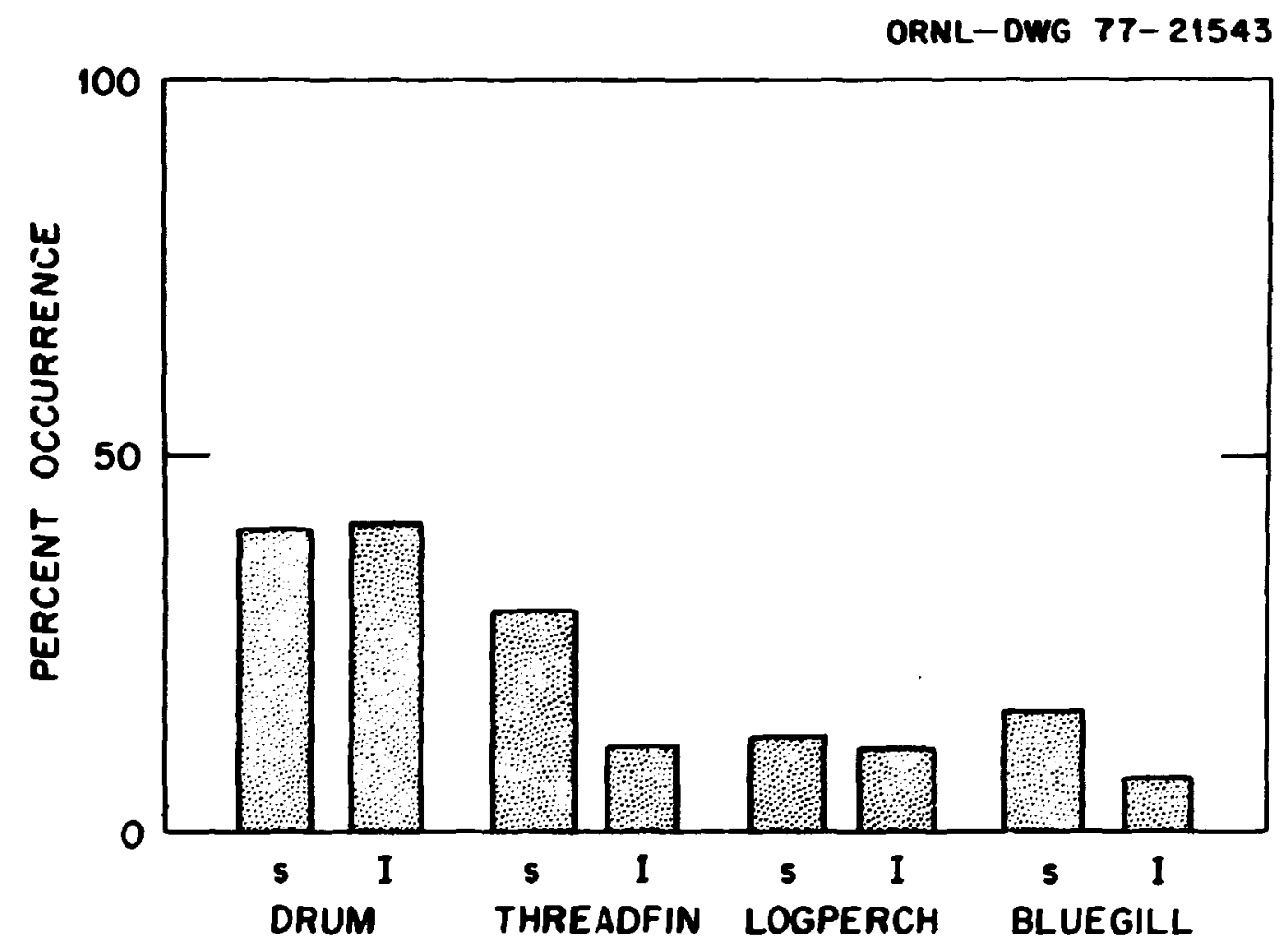

Figure A4. Comparison of sauger predation on fish species ( $s$ ) and impingement of these species (I), between 2 February and 26 April 1977. (Source, Mclean et al. 1978). 